\title{
Giving in the Aftermath of $9 / 11$ \\ An Update on the Foundation and Corporate Response
}

\section{NOVEMBER 2002}

\author{
Loren Renz \\ Vice President for Research
}

Contributors:

Elizabeth Cuccaro

September 11 Philanthropic Response Project Coordinator

Leslie A. Marino

Research Assistant

Mirek Drozdzowski

Special Projects Associate

The 


\section{Introduction}

The unprecedented outpouring of charitable support that followed the September 11, 2001, terrorist attacks prompted the Foundation Center to launch a multi-year effort to track relief and recovery funding by foundations, corporations, and other institutional donors. Our goal is to provide a definitive record of their philanthropic response to these tragic events. In the first phase of the project-spanning the year following the attacks-we built a comprehensive database of institutional donors that reported contributions in response to $9 / 11$. In the second phase, continuing through 2003, we will track the distribution or use of donations by recipient organizations. Beyond compiling these data, the Foundation Center will strive to place $9 / 11$ funding by foundations and corporations in the context of all private giving in response to the tragedy and to assess the impact of their relief and recovery support on their overall giving patterns.

This report provides an overview of $9 / 11$ giving by institutional donors based on data compiled through September 2002. It updates and expands the findings on funding patterns presented in the Foundation Center's first report on giving in response to the $9 / 11$ attacks. ${ }^{1}$ The latest information is based primarily on 2002 surveys of 9/11 donors. ${ }^{2}$ Information also comes from grantmaker news releases, Web sites of grantmaker associations, and donor lists compiled by leading recipients, such as the September 11th Fund of the United Way of New York and the New York Community Trust and the American Red Cross.

The Foundation Center's database contains the most complete national record of institutional funding related to $9 / 11$ and its aftermath. However, it is still a work in progress, and reporting remains incomplete. For example, the database includes pledges that are as yet undesignated and donations to named organizations for unspecified amounts.

The Foundation Center will continue to collect and refine the data on donors and recipients. In 2003, these efforts will include indexing the purposes and beneficiaries of $9 / 11$ gifts and surveying recipients about the ultimate uses of these funds. In the fall, the Foundation Center will publish a report focusing on $9 / 11$ recipients. In the interim, at our Web site we have created a searchable database on foundation and corporate $9 / 11$ response funding and posted copies of this and earlier reports on 9/11 giving in PDF format (see www.fdncenter.org/research/911/).

\section{Donors}

Institutional donors include corporations and corporate foundations; independent and family foundations; community foundations and other public foundations; and a variety of associations.

- The Foundation Center has identified 1,000 foundations, corporations, and other institutional donors that have together contributed over $\$ 1.0$ billion for relief and recovery efforts and for purposes related to the $9 / 11$ attacks and their aftermath (Table 1). ${ }^{3}$ The sweeping breadth of the response has proven a milestone for philanthropy. Prior to $9 / 11$, the institutional philanthropic response to natural disasters and other regional or international crises had been far narrower in scope.

- Giving by institutional donors represented 39 percent of an estimated $\$ 2.6$ billion in total private giving in response to $9 / 11$ (Figure 1 ). ${ }^{4}$ This proportion was more than double the 17 percent

TABLE 1. Foundation/Corporate 9/11 Response Funding by Donor Type*

\begin{tabular}{|c|c|c|c|c|c|c|c|}
\hline Donor Type & $\begin{array}{l}\text { No. of } \\
\text { Donors }\end{array}$ & $\%$ & & Amount $^{1}$ & $\%$ & No. of Gifts & $\%$ \\
\hline Corporations/Corporate Foundations & 568 & 56.8 & $\$$ & $682,394,281$ & 67.5 & 989 & 38.5 \\
\hline Independent and Family Foundations & 255 & 25.5 & & $261,510,938$ & 25.9 & 1,231 & 48.0 \\
\hline Community Foundations & 110 & 11.0 & & $18,009,644$ & 1.8 & 209 & 8.1 \\
\hline Other Public Foundations & 52 & 5.2 & & $29,644,152$ & 2.9 & 121 & 4.7 \\
\hline Associations/Other & 15 & 1.5 & & $19,835,700$ & 2.0 & 16 & 0.6 \\
\hline TOTAL & 1,000 & 100.0 & & $1,011,394,715$ & 100.0 & 2,566 & 100.0 \\
\hline
\end{tabular}

Source: Giving in the Aftermath of 9/11, The Foundation Center, November 2002.

*Due to rounding, percentages may not total 100.

${ }^{1}$ Includes cash donations and amounts pledged to match employee gifts; excludes in-kind donations. 
FIGURE 1. Foundation/Corporate 9/11 Response Funding as a Share of All Private Giving

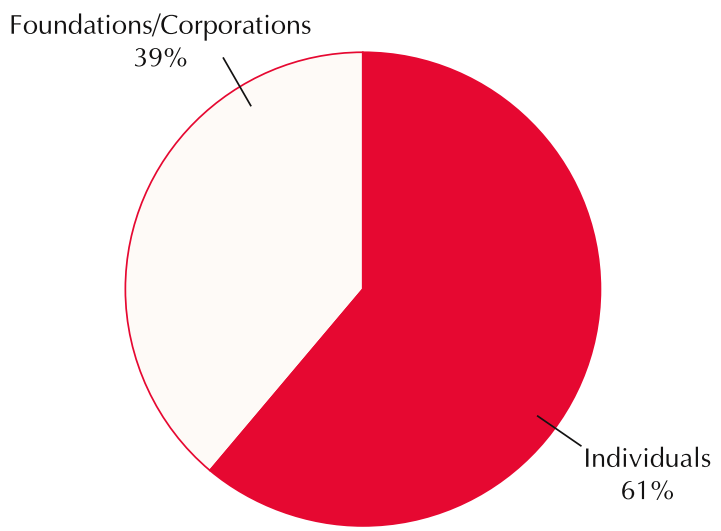

All Private $\mathbf{9} / 11$ Giving $=\$ 2.6$ billion 1

Source: Giving in the Aftermath of 9/11, The Foundation Center, November 2002.

${ }^{1}$ Estimate includes $\$ 2.3$ billion received by major relief funds and reported by The Chronicle of Philanthropy (9/5/02) and an additional $\$ 250+$ million in $9 / 11$ donations reported by institutional donors and tracked by the Foundation Center.

share of all U.S. private giving provided by foundations and corporations in $2001 .^{5}$

- Foundations and corporations reported a total of 2,566 donations, but the proportion of unspecified funding remains substantial. The number of gifts in the database will continue to rise as donors fulfill their undesignated pledges and report the exact amounts given to named recipients. ${ }^{6}$

\section{By Funder Type}

- 568 corporations pledged $\$ 682.4$ million, or 67 percent of all institutional funding in response to the $9 / 11$ attacks (Figure 2). ${ }^{7}$ This figure includes cash donations and more than $\$ 110$ million pledged to match employee gifts. ${ }^{8}$ (In-kind gifts are excluded from this analysis.)

- Corporate donors reported 989 donations to named recipient groups, mainly $9 / 11$ relief funds. These donations accounted for less than two-fifths of all designated gifts. If reporting of gifts were more complete, the number of gifts would increase substantially.

- Among various types of corporate donors were 222 corporate foundations. They contributed \$349.1 million, or 51 percent of all corporate 9/11 giving (Figure 3 ). This is roughly double the proportion of total annual corporate giving typically provided by corporate foundations. Possible explanations for this higher proportion include corporations' use of their foundation endowments to help fund the unbudgeted 9/11 donations and the use of their foundations for matching employee contributions and providing assistance to victims or their families.

- 417 independent and community or other public foundations pledged $\$ 309.2$ million, or 31 percent of institutional 9/11 funding. Independent foundations alone provided \$261.5 million, while community foundations

FIGURE 2. Foundation/Corporate 9/11 Response Funding by Donor Type*

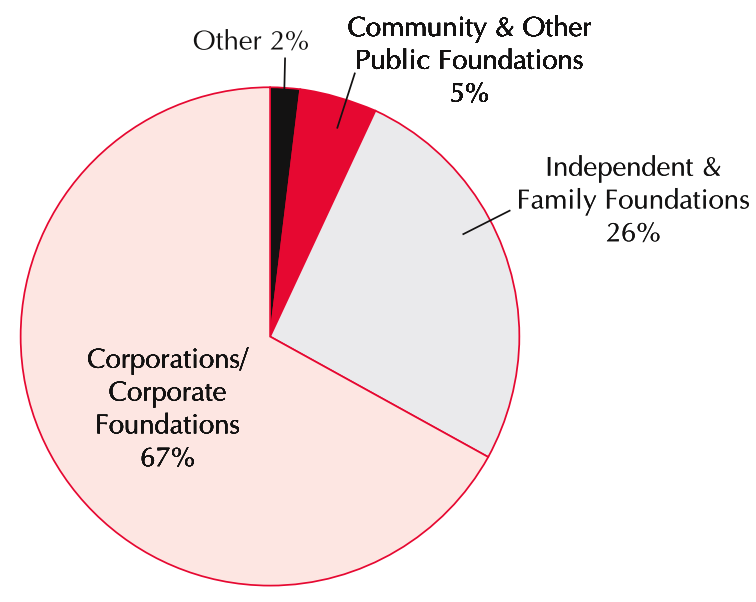

Total 9/11 Giving $=\$ 1,011.4$ million

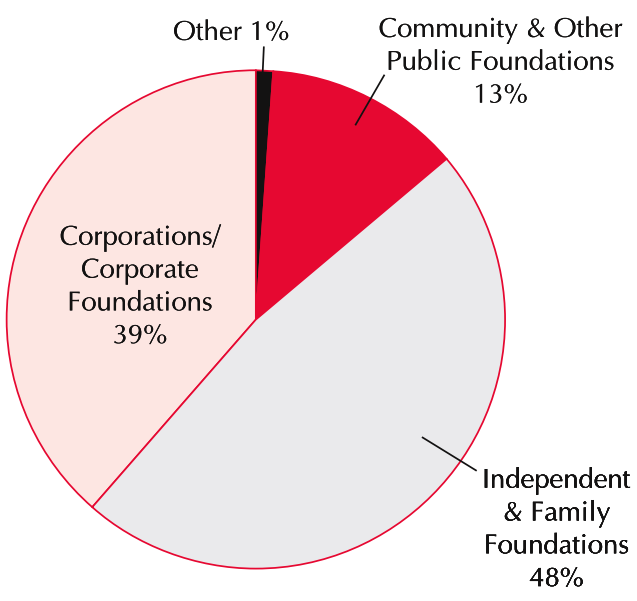

No. of 9/11 Gifts $=2,566$ 
FIGURE 3. Corporate Foundation Giving as a Share of All Corporate 9/11 Giving

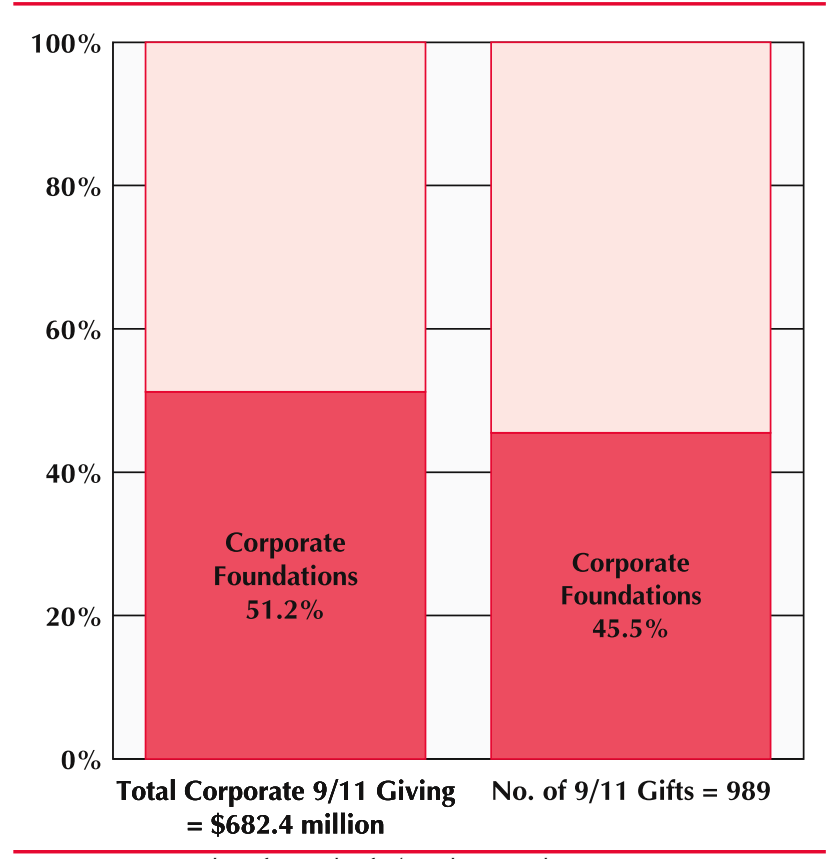

Source: Giving in the Aftermath of 9/11, The Foundation Center, November 2002.

contributed $\$ 18.0$ million and other public foundations gave $\$ 29.7$ million.

- Independent and community or other public foundations reported 1,561 gifts to specific recipient organizations, or more than three-fifths of all institutional gifts reported. Independent foundations alone made 1,231 gifts, or 48 percent of all designated gifts. In addition to supporting relief funds, larger independent foundations supported a wide range of local and national direct service providers, groups directly affected by the 9/11 attacks, and organizations addressing issues related to the attacks and their aftermath. (See "Recipients" for an analysis of 9/11 giving to recipient organizations.)

- 15 associations, including business groups, sports groups, and trade unions pledged $\$ 19.8$ million, or over 2 percent of the total. They reported only 16 gifts, or less than 1 percent of designated gifts. Like corporations, they mainly channeled their support through $9 / 11$ relief funds.

\section{By Range of Giving}

- Giving per funder ranged from less than $\$ 500$ for a small community foundation in Michigan to the $\$ 50$ million pledged by the New York-based Andrew W. Mellon Foundation, one of the ten largest U.S. independent foundations. Among corporations, giving ranged from less than $\$ 5,000$ to the $\$ 16.2$ million pledged by ExxonMobil through its foundation.

- Nearly two-thirds (64 percent) of all institutional donors gave less than $\$ 500,000$ for $9 / 11$ relief and recovery (Table 2 ). The median amount-the mid-point for all donors ranked by giving - was $\$ 125,000$, but it varied widely by donor type. Among the principal donor types in the Foundation Center's 9/11 database, the median giving amount ranged from $\$ 70,000$ for independent foundations, including family foundations, to $\$ 369,000$ for corporations overall and $\$ 500,000$ for corporate foundations. For community foundations it was $\$ 31,000$; for other public foundations, $\$ 100,000$; and for associations, $\$ 575,000$.

TABLE 2. Foundation/Corporate 9/11 Response Funding By Range of Giving*

\begin{tabular}{|c|c|c|c|c|}
\hline Range of $9 / 11$ Giving & No. of Donors & $\%$ & Amount ${ }^{1}$ & $\%$ \\
\hline$\$ 10$ million and over & 27 & 2.7 & $\$ 383,573,066$ & 37.9 \\
\hline \$5 million-\$10 million & 38 & 3.8 & $215,504,937$ & 21.3 \\
\hline \$2 million-\$5 million & 49 & 4.9 & $122,421,937$ & 12.1 \\
\hline \$1 million-\$2 million & 175 & 17.5 & $189,163,962$ & 18.7 \\
\hline$\$ 500,000-\$ 1$ million & 76 & 7.6 & $44,159,016$ & 4.4 \\
\hline$\$ 250,000-\$ 500,000$ & 75 & 7.5 & $23,271,482$ & 2.3 \\
\hline$\$ 100,000-\$ 250,000$ & 175 & 17.5 & $22,503,779$ & 2.2 \\
\hline$\$ 50,000-\$ 100,000$ & 100 & 10.0 & $6,058,376$ & 0.6 \\
\hline$\$ 25,000-\$ 50,000$ & 96 & 9.6 & $2,904,586$ & 0.3 \\
\hline Less than $\$ 25,000$ & 189 & 18.9 & $1,833,574$ & 0.2 \\
\hline TOTAL & 1,000 & 100.0 & $\$ 1,011,394,715$ & 100.0 \\
\hline
\end{tabular}

Source: Giving in the Aftermath of 9/11, The Foundation Center, November 2002.

*Due to rounding, percentages may not total 100.

${ }^{1}$ Includes cash donations and amounts pledged to match employee gifts; excludes in-kind donations. 
- 289 donors, or less than 30 percent, contributed $\$ 1$ million or more for relief and recovery efforts. Together they gave $\$ 910.7$ million, or 90 percent of total funding.

- \$1 million+ contributors included 225 corporations, 43 independent foundations, 10 public foundations, 6 associations, and 5 community foundations. Forty percent of the corporate donors gave $\$ 1$ million or more in 9/11 response funding, compared to roughly 13 percent of the independent and community foundations.

- 65 donors—less than 7 percent—pledged $\$ 5$ million or more. Their contributions totaled $\$ 599.1$ million, or 59 percent of institutional 9/11 giving. The proportion of funding provided by the largest contributors varied by donor type. For example, 46 corporations - or 8 percent of the corporate donors-reported giving $\$ 5$ million or more, and they represented 55 percent of the corporate giving (Figure 4). In contrast, only 14 independent or community foundations-just 4 percent-gave $\$ 5$ million or more, yet they provided 70 percent of $9 / 11$ giving by independent and community foundations.

- Ten corporate contributors gave in excess of $\$ 10$ million: ExxonMobil (TX), Citigroup (NY), General Electric (CT), Deutsche Bank (NY), Verizon (NY), Coca-Cola (GA), J.P. Morgan Chase (NY), ChevronTexaco (CA), Fannie Mae (DC), and Philip Morris (NY) (Table 3). Seven of the top ten corporate donors made their $9 / 11$ gifts from their foundations.

- Foundation donors that gave at least \$10 million each included the Andrew W. Mellon Foundation (NY), Lilly Endowment (IN), Starr Foundation (NY), Ford Foundation (NY), Carnegie Corporation (NY), California Endowment (CA), and Atlantic Philanthropies (NY) (Table 4). ${ }^{9}$

FIGURE 4. Foundation vs. Corporate 9/11 Response Funding by Range of Giving*
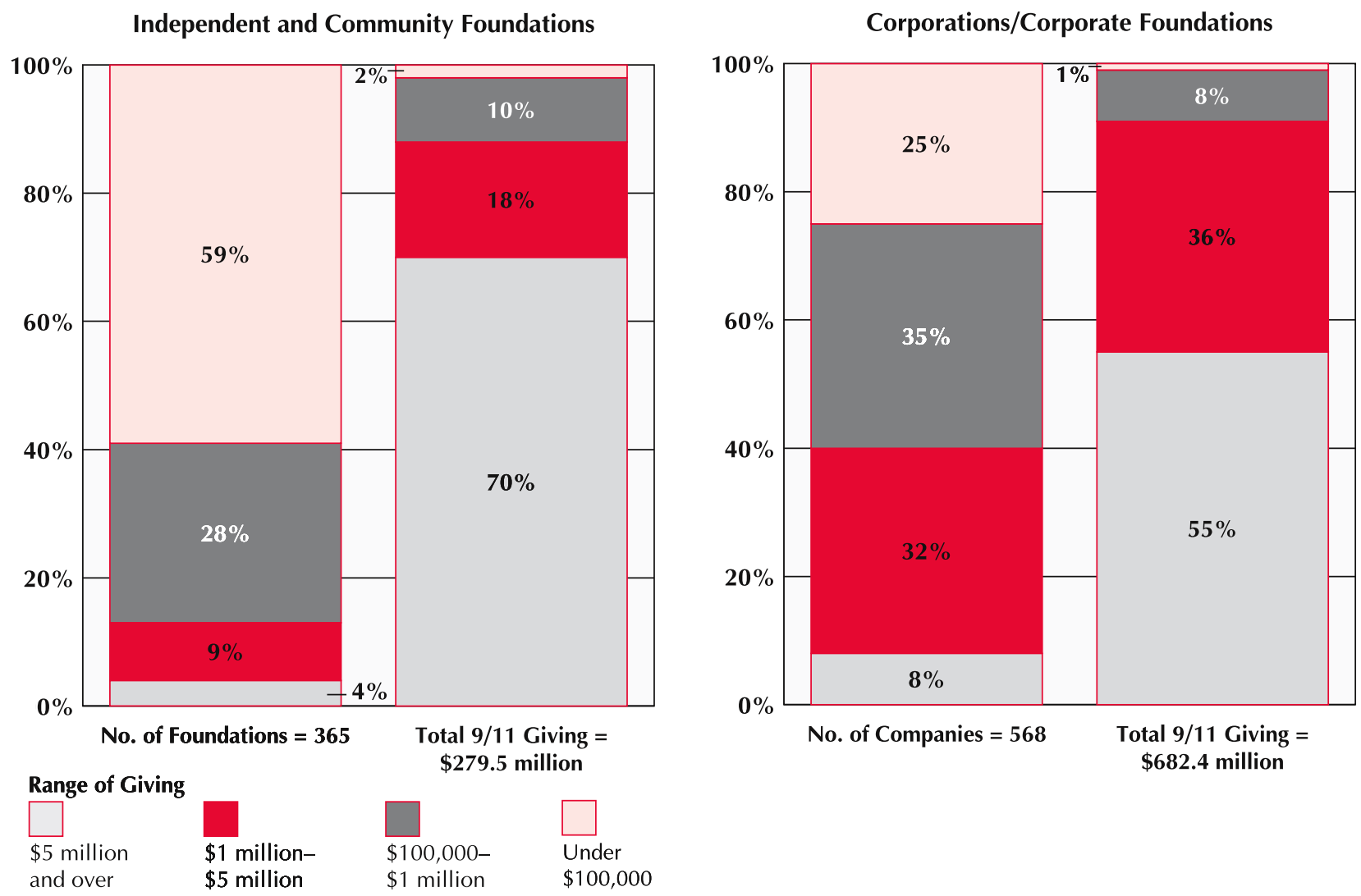

Source: Giving in the Aftermath of 9/11, The Foundation Center, November 2002.

*Based on total giving figures for latest fiscal year reported (2001 for most foundations, 2000 for others); due to rounding, percentages may not total 100. 
TABLE 3. Top 25 Corporate Donors Ranked By Total 9/11 Response Funding*

\begin{tabular}{|c|c|c|c|c|}
\hline & Corporation/Corporate Foundation & State & Amount ${ }^{1}$ & Purpose of Funding \\
\hline 1. & ExxonMobil Foundation & TX & $\$ 16,250,000$ & $\begin{array}{l}\text { To support various relief and recovery organizations through employee, } \\
\text { retiree, dealer, and distributor matching gift programs. }\end{array}$ \\
\hline 2. & Citigroup Foundation & NY & $15,191,000$ & $\begin{array}{l}\text { To establish the Citigroup Relief Fund for scholarships for the children of } \\
\text { victims and to provide disaster assistance to various NYC nonprofits. }\end{array}$ \\
\hline 3. & GE Fund & CT & $15,000,000$ & $\begin{array}{l}\text { To support the Twin Towers Fund and the American Red Cross Liberty } \\
\text { Disaster Relief Fund. }\end{array}$ \\
\hline 4. & Deutsche Bank Americas Foundation & NY & $14,597,823$ & $\begin{array}{l}\text { To support the } 9 / 11 \text { Widows' and Children's Benefit Fund and various } \\
\text { organizations helping with relief and recovery. }\end{array}$ \\
\hline 5. & Verizon Foundation & NY & $12,625,000$ & $\begin{array}{l}\text { To support the } 9 / 11 \text { Widows' and Children's Benefit Fund, the American Red } \\
\text { Cross Liberty Disaster Relief Fund (and local chapters), and the September } \\
11 \text { th Fund. }\end{array}$ \\
\hline 6. & Coca-Cola Company & GA & $12,000,000$ & $\begin{array}{l}\text { To support the American Red Cross Liberty Disaster Relief Fund and various } \\
\text { organizations assisting the children of victims. }\end{array}$ \\
\hline 7. & J.P. Morgan Chase Foundation & NY & $11,972,956$ & $\begin{array}{l}\text { To establish the J. P. Morgan Chase WTC Disaster Relief Fund to aid victims } \\
\text { and families. }\end{array}$ \\
\hline 8. & ChevronTexaco Corporation & $\mathrm{CA}$ & $10,500,000$ & $\begin{array}{l}\text { To support the American Red Cross (NY and DC), the September } 11 \text { th Fund, } \\
\text { NYSE Fallen Heroes Fund, Marsh and McLennan Victims' Relief Fund, and } \\
\text { the Metropolitan Opera Fundraiser for Disaster Relief. }\end{array}$ \\
\hline 9. & Fannie Mae Foundation & DC & $10,050,000$ & $\begin{array}{l}\text { To support various organizations including the Community Foundation for } \\
\text { the National Capital Region Survivors' Fund, REALTORS Housing Relief } \\
\text { Fund, September 11th Fund, and the DC Disaster Relief Fund. }\end{array}$ \\
\hline 10. & Philip Morris Companies & NY & $10,042,000$ & $\begin{array}{l}\text { To support various organizations including the American Red Cross Liberty } \\
\text { Disaster Relief Fund and the September 11th Fund. }\end{array}$ \\
\hline 11. & AXA Foundation & NY & $10,000,000$ & To establish the AXA 9/11 Relief Fund aiding those affected by $9 / 11$. \\
\hline 12. & Bear, Stearns \& Co. & NY & $10,000,000$ & To establish the Bear Stearns Relief Fund to benefit victims and families. \\
\hline 13. & DaimlerChrysler Corporation & MI & $10,000,000$ & $\begin{array}{l}\text { To establish the DaimlerChrysler Help the Children Fund to benefit the } \\
\text { children of those killed or injured in the attacks. }\end{array}$ \\
\hline 14. & Freddie Mac Foundation & VA & $10,000,000$ & $\begin{array}{l}\text { To support various relief organizations providing for the short-term needs of } \\
\text { survivors and families of victims and long-term relief for victims' families. }\end{array}$ \\
\hline 15. & Goldman Sachs Foundation & NY & $10,000,000$ & To establish the Goldman Sachs Relief Fund to aid victims and families. \\
\hline 16. & Johnson \& Johnson Family of Companies & NJ & $10,000,000$ & $\begin{array}{l}\text { To support the American Red Cross Liberty Disaster Relief Fund, September } \\
11 \text { th Fund, and various organizations to help speed relief and recovery. }\end{array}$ \\
\hline 17. & Lehman Brothers & NY & $10,000,000$ & To support various relief and recovery organizations. \\
\hline 18. & Marsh \& McLennan Companies & NY & $10,000,000$ & $\begin{array}{l}\text { To establish the Marsh \& McLennan Victims' Relief Fund to aid victims and } \\
\text { families. }\end{array}$ \\
\hline 19. & Merrill Lynch \& Co. & NY & $10,000,000$ & To support various relief and recovery organizations. \\
\hline 20. & Morgan Stanley Dean Witter \& Co. & NY & $10,000,000$ & $\begin{array}{l}\text { To establish the Morgan Stanley Victims Relief Fund to aid victims and } \\
\text { families. }\end{array}$ \\
\hline 21. & Pfizer/Pfizer Foundation & NY & $9,263,500$ & $\begin{array}{l}\text { To support the Twin Towers Fund, September } 11 \text { th Fund, American Red } \\
\text { Cross Liberty Disaster Relief Fund, and various relief organizations. }\end{array}$ \\
\hline 22. & $\begin{array}{l}\text { Anheuser-Busch Family of Wholsesalers/ } \\
\text { Anheuser-Busch Foundation }\end{array}$ & $\mathrm{MO}$ & $8,400,000$ & $\begin{array}{l}\text { To support the NYS World Trade Center Relief Fund, September 11th Fund, } \\
\text { Community Foundation for the National Capital Region Survivors' Fund, } \\
\text { the American Red Cross (for long-term personal needs of victims and } \\
\text { families), and the Salvation Army (to provide meals for emergency workers } \\
\text { in NY and DC). }\end{array}$ \\
\hline 23. & Vivendi Universal Foundation & NY & $8,000,000$ & $\begin{array}{l}\text { To support the September } 11 \text { th Fund, Robin Hood Relief Fund (to underwrite } \\
\text { the Concert for NYC), and various organizations through employee } \\
\text { matching gift programs. }\end{array}$ \\
\hline 24. & Credit Suisse First Boston & NY & $6,648,345$ & $\begin{array}{l}\text { To support various relief and recovery organizations including the } 9 / 11 \\
\text { Widows' and Children's Benefit Fund and the Children's Aid Society WTC } \\
\text { Relief Fund. }\end{array}$ \\
\hline 25. & Prudential Foundation & NJ & $6,163,407$ & $\begin{array}{l}\text { To establish the Prudential CARES Disaster Relief Fund to aid victims and } \\
\text { families. }\end{array}$ \\
\hline
\end{tabular}

Source: Giving in the Aftermath of 9/11, The Foundation Center, November 2002.

*Aggregate corporate giving information in other tables and figures is based on data reported through September 20, 2002. Giving data on individual companies included in this table may be more current.

${ }^{1}$ Includes cash donations and amounts pledged to match employee gifts; excludes in-kind donations. 
TABLE 4. Top 20 Independent and Operating Foundations Ranked By Total 9/11 Response Funding*

\begin{tabular}{|c|c|c|c|c|c|}
\hline & Foundation & State & $\begin{array}{l}\text { Foundation } \\
\text { Type }^{1}\end{array}$ & Amount & Purpose of Funding \\
\hline 1. & Andrew W. Mellon Foundation & NY & IN & $\$ 50,000,000$ & $\begin{array}{l}\text { To assist NYC cultural and performing arts organizations directly affected } \\
\text { by September } 11 \text { th; support also for various organizations' New York } \\
\text { disaster response. }\end{array}$ \\
\hline 2. & Lilly Endowment & IN & IN & $34,600,000$ & $\begin{array}{l}\text { To support the American Red Cross Liberty Disaster Relief Fund, the } \\
\text { September } 11 \text { th Fund, and the Salvation Army's national disaster } \\
\text { training project for faith-based disaster relief organizations. }\end{array}$ \\
\hline 3. & Starr Foundation & NY & IN & $18,036,446$ & $\begin{array}{l}\text { To support the } 9 / 11 \text { Widows' and Children's Benefit Fund, the NYC Police } \\
\text { Foundation's Heroes Fund, and various NYC nonprofit organizations } \\
\text { affected by September } 11 \text { th; support also for a matching gift program for } \\
\text { AIG employees. }\end{array}$ \\
\hline 4. & Ford Foundation & NY & IN & $15,889,800$ & $\begin{array}{l}\text { To support the September } 11 \text { th Fund, nonprofits directly affected by the } \\
\text { WTC disaster, and those working to promote public discourse on issues } \\
\text { related to September } 11 \text { th. }\end{array}$ \\
\hline 5. & Carnegie Corporation & NY & IN & $13,450,000$ & $\begin{array}{l}\text { To support various educational and media-related organizations dealing } \\
\text { with public awareness and response to the aftermath of the attacks; } \\
\text { support also for NYC cultural organizations through an anonymous \$10 } \\
\text { million gift. }\end{array}$ \\
\hline 6. & California Endowment & $\mathrm{CA}$ & IN & $13,318,041$ & $\begin{array}{l}\text { To support workers and nonprofit organizations in California affected by } \\
\text { September } 11 \text { th; support also for CA-based nonprofits working to } \\
\text { promote intercultural communication, religious tolerance, conflict } \\
\text { resolution, and violence prevention. }\end{array}$ \\
\hline 7. & Atlantic Philanthropies ${ }^{2}$ & NY & IN & $10,050,000$ & To support the September 11th Fund and Meals On Wheels. \\
\hline 8. & $\begin{array}{l}\text { John S. and James L. Knight } \\
\text { Foundation }\end{array}$ & $\mathrm{FL}$ & IN & $8,786,000$ & $\begin{array}{l}\text { To support various relief-related activities for the secondary economic victims } \\
\text { of September } 11 \text { th in the } 26 \text { communities served by the foundation and for } \\
\text { memorial efforts honoring hijacking victims of Flight } 93 \text {. }\end{array}$ \\
\hline 9. & $\begin{array}{l}\text { William Randolph Hearst } \\
\text { Foundation }\end{array}$ & NY & IN & $6,100,000$ & $\begin{array}{l}\text { To support the Lower Manhattan Small Business and Workforce Retention } \\
\text { Project, the Asian American Federation WTC Fund (for technical } \\
\text { assistance programs and recovery efforts), and various relief } \\
\text { organizations. }\end{array}$ \\
\hline 10. & W. K. Kellogg Foundation & MI & IN & $5,635,492$ & $\begin{array}{l}\text { To support various educational and community outreach organizations } \\
\text { that provided support to communities and population groups affected by } \\
\text { the attacks. }\end{array}$ \\
\hline 11. & Alfred P. Sloan Foundation & NY & IN & $5,230,597$ & $\begin{array}{l}\text { To support the September } 11 \text { th Fund and various educational institutions } \\
\text { responding to the needs of those affected in NYC and Washington, DC, } \\
\text { and seeking to prevent the threat of bioterrorism through research and } \\
\text { program development. }\end{array}$ \\
\hline 12. & $\begin{array}{l}\text { John D. and Catherine T. } \\
\text { MacArthur Foundation }\end{array}$ & IL & IN & $5,155,000$ & $\begin{array}{l}\text { To support organizations addressing issues arising from September } 11 \text { th } \\
\text { related to strengthening the quality of public information and analysis, } \\
\text { understanding the underlying causes of terrorism, and determining the } \\
\text { implications for civil liberties. }\end{array}$ \\
\hline 13. & Rockefeller Foundation & NY & IN & $5,092,596$ & $\begin{array}{l}\text { To support various relief organizations and organizations providing } \\
\text { protection and support to minority communities in NYC, particularly } \\
\text { Arab, South Asian, and Muslim communities. }\end{array}$ \\
\hline 14. & $\begin{array}{l}\text { Robert Wood Johnson } \\
\text { Foundation }\end{array}$ & NJ & IN & $5,000,000$ & $\begin{array}{l}\text { To support the September } 11 \text { th Fund and various relief and recovery } \\
\text { efforts, including public health services, counseling, and direct aid to } \\
\text { recovery workers. }\end{array}$ \\
\hline 15. & Charles Stewart Mott Foundation & MI & IN & $3,643,737$ & $\begin{array}{l}\text { To support the September } 11 \text { th Fund, American Red Cross Liberty Disaster } \\
\text { Relief Fund, and various organizations dealing with the aftermath of the } \\
\text { attacks. }\end{array}$ \\
\hline 16. & Annie E. Casey Foundation & MD & IN & $3,000,000$ & $\begin{array}{l}\text { To support various organizations providing assistance to the children and } \\
\text { families directly affected by the attacks. }\end{array}$ \\
\hline 17. & Bill \& Melinda Gates Foundation & WA & IN & $3,000,000$ & $\begin{array}{l}\text { To support the September } 11 \text { th Fund, the New York Times 9/11 Neediest } \\
\text { Cases Fund, and the American Red Cross Liberty Disaster Relief Fund. }\end{array}$ \\
\hline 18. & Lumina Foundation for Education & MN & IN & $3,000,000$ & To support the Families of Freedom Scholarship Fund. \\
\hline 19. & Open Society Institute & NY & $\mathrm{OP}$ & $2,520,000$ & $\begin{array}{l}\text { To support various organizations that promote policy development, } \\
\text { advocacy, and monitoring pertaining to civil liberties of immigrant and } \\
\text { minority groups affected by } 9 / 11 \text {. }\end{array}$ \\
\hline \multirow[t]{2}{*}{20.} & $\begin{array}{l}\text { William R. Kenan, Jr., Charitable } \\
\text { Trust }\end{array}$ & NC & IN & $2,500,000$ & To provide scholarships to NYC uniformed services personnel. \\
\hline & $\begin{array}{l}\text { Robert R. McCormick Tribune } \\
\text { Foundation }\end{array}$ & IL & IN & $2,500,000$ & $\begin{array}{l}\text { To establish the McCormick Tribune Disaster Relief Fund to aid } \\
\text { organizations providing services to the victims of the attacks, their } \\
\text { families, and those in the impacted communities. }\end{array}$ \\
\hline
\end{tabular}

Source: Giving in the Aftermath of 9/11, The Foundation Center, November 2002.

*Aggregate foundation giving information in other tables and figures is based on data reported through September 20, 2002. Giving data on individual foundations included in this table may be more current.

${ }^{1}$ Includes independent and family (IN) and operating foundations (OP); excludes company-sponsored foundations.

${ }^{2}$ An international endowed philanthropy with a principal domicile outside the U.S., it operates like an independent foundation and maintains a grant selection and administration office in New York. 


\section{By Funder Location}

- While corporations, foundations, and other institutional donors across the United States and abroad responded generously to the $9 / 11$ terrorist attacks, New York State-based corporations and foundations provided more than two-fifths of all 9/11 response funding ( $\$ 418.2$ million) (Figure 5 and Table 6). Tri-state (NY, NJ, CT) grantmakers together contributed over half of the support (\$517.0 million). Six of the top ten independent foundations, six of the top ten public foundations, and six of the ten corporate donors giving \$10 million or more were located in New York State or in the tri-state area.

- California ranked second after New York among states providing institutional philanthropic support, with nearly 9 percent of funding $(\$ 86.8$ million). California Endowment, the largest California 9/11 donor, ranked sixth among independent foundation donors.

- 26 donors-mainly corporations-based outside of the United States provided nearly 2 percent of 9/11 response funding (\$18.1 million). Canada accounted for the largest number of donors (10) and the largest giving amount (\$8.0 million), followed by Japan and the Netherlands. It should be noted that many foreign and multinational companies donated $9 / 11$ funds through their U.S.-based affiliates. Therefore, the total amount reported does not represent all funding from overseas corporations and foundations.

\section{By Funder Size}

The following analysis of 9/11 giving by funder size is limited to independent, community, and corporate foundations, for which asset information is available in the Foundation Center's foundation database. ${ }^{10}$ While not all foundations maintain large endowments relative to their giving, asset size nevertheless provides one criterion for assessing giving capacity.

- Larger foundations represented the majority of 9/11 donors identified by the Foundation Center. Three-quarters of independent and community foundation 9/11 donors held $\$ 10$ million or more in assets in their latest fiscal year, while more than half held at least $\$ 50$ million in assets (Figure 6 and Table 7). ${ }^{11}$

- Large foundations provided the vast majority of 9/11 support. The 187 foundation 9/11 donors holding at least $\$ 50$ million in assets accounted

TABLE 5. Top 10 Community and Other Public Foundations and Associations Ranked By Total 9/11 Response Funding*

\begin{tabular}{|c|c|c|c|c|c|}
\hline & Donor Name & State & Donor Type $^{1}$ & Amount & Purpose of Funding \\
\hline 1. & Robin Hood Foundation & NY & PC & $\$ 7,000,000$ & $\begin{array}{l}\text { To establish the Robin Hood Relief Fund for organizations helping } \\
\text { victims and families, uniformed service workers, and low-income } \\
\text { victims impacted by the resulting economic downturn. }\end{array}$ \\
\hline 2. & Major League Baseball Charity & NY & PC & $5,000,000$ & $\begin{array}{l}\text { To establish the MLB-MLBPA Disaster Relief Fund to aid victims and } \\
\text { families. }\end{array}$ \\
\hline 3. & $\begin{array}{l}\text { Major League Baseball Players } \\
\text { Association }\end{array}$ & NY & AS & $5,000,000$ & $\begin{array}{l}\text { To establish the MLB-MLBPA Disaster Relief Fund to aid victims and } \\
\text { families. }\end{array}$ \\
\hline 4. & $\begin{array}{l}\text { National Association of Theatre } \\
\text { Owners }\end{array}$ & CA & AS & $5,000,000$ & To support various relief and recovery organizations. \\
\hline 5. & $\begin{array}{l}\text { National Collegiate Athletic } \\
\text { Association }\end{array}$ & IN & AS & $5,000,000$ & $\begin{array}{l}\text { To support the Families of Freedom Scholarship Fund to benefit } \\
\text { former or current NCAA student-athletes, firefighters, police } \\
\text { officers, and emergency medical technicians who were } \\
\text { permanently disabled as a result of the WTC tragedy. }\end{array}$ \\
\hline 6. & New York Community Trust & NY & $\mathrm{CM}$ & $2,180,000$ & $\begin{array}{l}\text { To support the September } 11 \text { th Fund, Twin Towers Fund, and local } \\
\text { NYC organizations directly involved in relief and recovery efforts. }\end{array}$ \\
\hline 7. & $\begin{array}{l}\text { Community Foundation of New } \\
\text { Jersey }\end{array}$ & NJ & $\mathrm{CM}$ & $2,040,000$ & To provide scholarships for individuals. \\
\hline 8. & Britney Spears Foundation & NY & PC & $2,000,000$ & To support the children of NYC police and firefighters. \\
\hline 9. & PGA Tour Charities & $\mathrm{FL}$ & PC & $2,000,000$ & To support various relief and recovery organizations. \\
\hline 10. & $\begin{array}{l}\text { Community Foundation of Silicon } \\
\text { Valley }\end{array}$ & CA & $\mathrm{CM}$ & $1,950,000$ & To support the September 11 th Fund. \\
\hline
\end{tabular}

Source: Giving in the Aftermath of 9/11, The Foundation Center, November 2002.

*Aggregate foundation giving information in other tables and figures is based on data reported through September 20, 2002. Giving data on individual grantmakers included in this table may be more current.

${ }^{1} \mathrm{AS}=$ Association; $\mathrm{CM}=$ Community Foundation; $\mathrm{PC}=$ Public Charity. 
for nearly nine-tenths of all 9/11 giving by independent and community foundations. The 30 foundation $9 / 11$ donors with assets of $\$ 1$ billion or more provided 72 percent of all foundation 9/11 giving (nearly \$201 million).

- Compared with independent and community foundations, the 222 corporate foundations that made $9 / 11$ gifts were more equally distributed by asset size. Less than half (46 percent) held

FIGURE 5. Foundation/Corporate 9/11 Response Funding by Donor State*

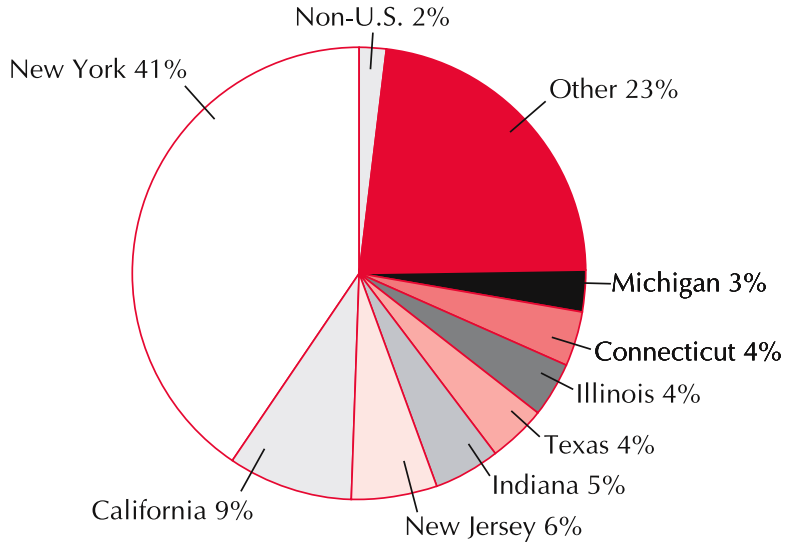

Total 9/11 Giving $=\$ 1,011.4$ million

Source: Giving in the Aftermath of 9/11, The Foundation Center, November 2002.

*Due to rounding, percentages may not total 100.

TABLE 6. Top 15 States by Total Foundation/Corporate 9/11 Response Funding

\begin{tabular}{|c|c|c|c|c|c|}
\hline State & $\begin{array}{c}\text { No. of } \\
\text { Donors }^{1}\end{array}$ & $\%$ & & Amount & $\%$ \\
\hline 1. New York & 183 & 18.2 & $\$$ & $418,176,189$ & 41.3 \\
\hline 2. California & 105 & 10.4 & & $86,797,494$ & 8.6 \\
\hline 3. New Jersey & 57 & 5.7 & & $63,639,075$ & 6.3 \\
\hline 4. Indiana & 18 & 1.8 & & $46,608,175$ & 4.6 \\
\hline 5. Texas & 47 & 4.7 & & $39,973,217$ & 4.0 \\
\hline 6. Illinois & 53 & 5.3 & & $36,797,142$ & 3.6 \\
\hline 7. Connecticut & 38 & 3.8 & & $35,168,028$ & 3.5 \\
\hline 8. Michigan & 40 & 4.0 & & $31,390,404$ & 3.1 \\
\hline 9. Georgia & 23 & 2.3 & & $22,963,791$ & 2.3 \\
\hline 10. Florida & 27 & 2.7 & & $22,344,368$ & 2.2 \\
\hline 11. Pennsylvania & 41 & 4.1 & & $18,464,444$ & 1.8 \\
\hline 12. Virginia & 20 & 2.0 & & $17,861,700$ & 1.8 \\
\hline 13. Washington & 15 & 1.5 & & $17,207,699$ & 1.7 \\
\hline 14. District of Columbia & 13 & 1.3 & & $15,898,398$ & 1.6 \\
\hline 15. Ohio & 40 & 4.0 & & $14,586,705$ & 1.4 \\
\hline Subtotal & 720 & 71.4 & $\$$ & $887,876,829$ & 87.8 \\
\hline All Other States & 262 & 26.0 & $\$$ & $105,394,152$ & 10.4 \\
\hline Non-U.S. ${ }^{2}$ & 26 & 2.6 & $\$$ & $18,123,734$ & 1.8 \\
\hline TOTAL & 1,008 & 100.0 & & ,011,394,715 & 100.0 \\
\hline
\end{tabular}

Source: Giving in the Aftermath of 9/11, The Foundation Center,

November 2002.

${ }^{1}$ Includes 5 corporate donors with funding sources in more than one location.

${ }^{2}$ Principal countries by amount of giving include Canada, Japan,

Netherlands, Germany, England, France, and Kuwait. assets of $\$ 10$ million or more, while fewer than 18 percent held at least $\$ 50$ million in assets.

Close to one-fifth of corporate foundation donors held less than $\$ 1$ million in assets (Figure 7 and Table 8 ). ${ }^{12}$

FIGURE 6. Distribution of Independent and Community Foundation 9/11 Response Funding by Foundation Asset Size*

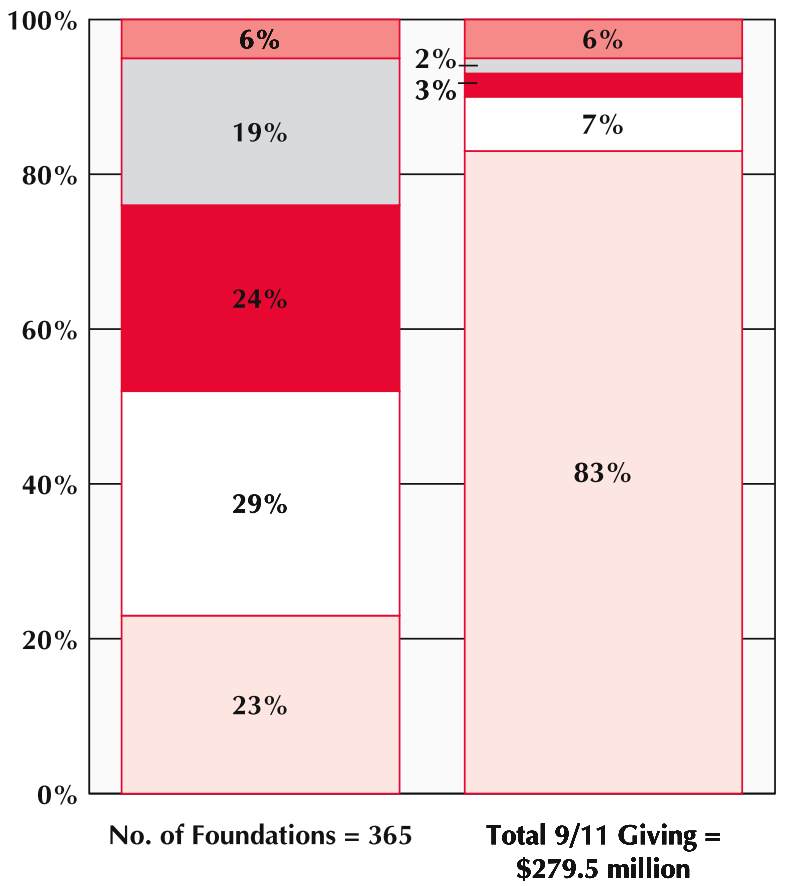

Asset Range

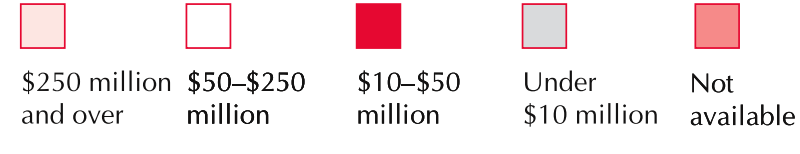

Source: Giving in the Aftermath of 9/11, The Foundation Center,

November 2002.

*Based on assets for latest fiscal year reported (2001 for most foundations,

2000 for others); due to rounding, percentages may not total 100

TABLE 7. Breakdown of Independent and Community Foundation 9/11 Response Funding by Foundation Asset Size*

\begin{tabular}{lcrrr}
\hline & $\begin{array}{c}\text { No. of } \\
\text { Fsset Range }\end{array}$ & \multicolumn{1}{c}{$\begin{array}{c}\text { 9/11 Giving } \\
\text { Amount }\end{array}$} & \multicolumn{1}{c}{$\%$} \\
\hline \$1 billion and over & 30 & 8.2 & $\$ 200,897,209$ & 71.9 \\
\$250 million-\$1 billion & 52 & 14.2 & $29,621,135$ & 10.6 \\
\$50 million-\$250 million & 105 & 28.8 & $18,445,788$ & 6.6 \\
\$10 million-\$50 million & 87 & 23.8 & $8,446,882$ & 3.0 \\
\$1 million-\$10 million & 47 & 12.9 & $3,637,579$ & 1.3 \\
Under \$1 million & 23 & 6.3 & $2,645,075$ & 0.9 \\
Not available & 21 & 5.8 & $15,826,914$ & 5.7 \\
\multicolumn{1}{c}{ TOTAL } & $\mathbf{3 6 5}$ & $\mathbf{1 0 0 . 0}$ & $\mathbf{\$ 2 7 9 , 5 2 0 , 5 8 2}$ & $\mathbf{1 0 0 . 0}$
\end{tabular}

Source: Giving in the Aftermath of 9/11, The Foundation Center,

November 2002

*Based on assets for latest fiscal year reported (2001 for most foundations,

2000 for others); due to rounding, percentages may not total 100 . 
- Despite the more even distribution of corporate foundation $9 / 11$ donors by asset size, larger corporate foundations also provided a majority of corporate foundation 9/11 funding. In the top asset ranges, those reporting assets of $\$ 10$ million or more accounted for two-thirds of all corporate foundation 9/11 giving. Those holding assets of $\$ 50$ million or more contributed 38 percent of all corporate foundation $9 / 11$ support.

FIGURE 7. Distribution of Corporate Foundation 9/11 Response Funding by Foundation Asset Size*

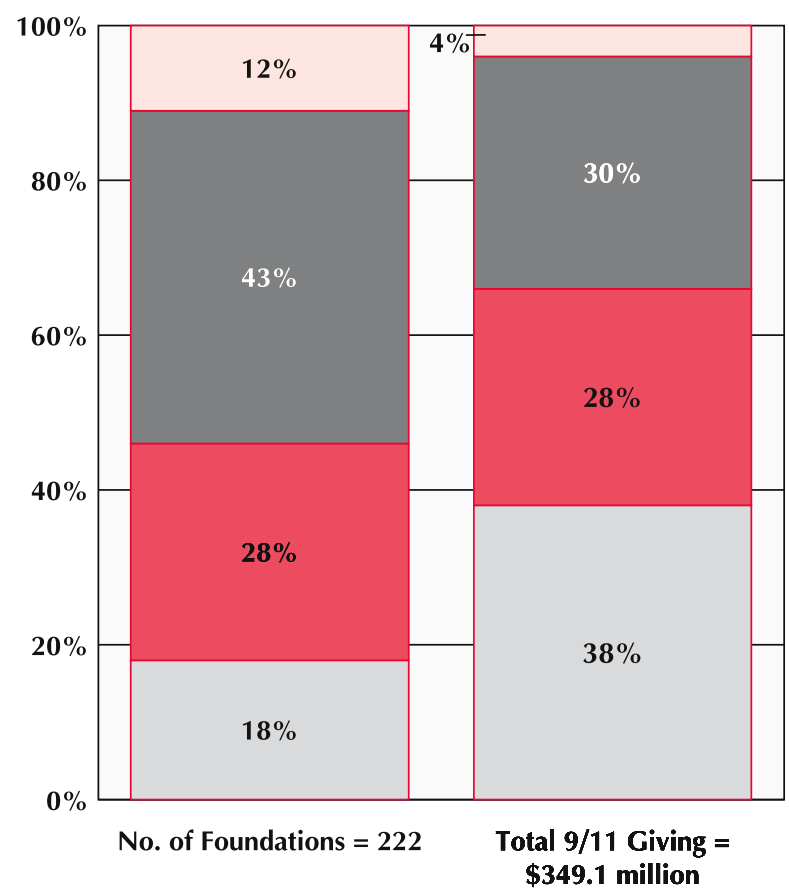

Asset Range

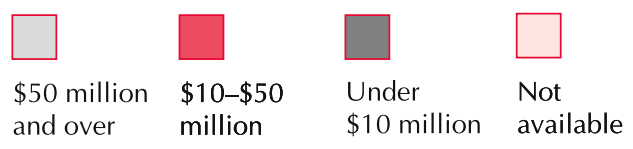

Source: Giving in the Aftermath of 9/11, The Foundation Center, November 2002.

*Due to rounding, percentages may not total 100 .

TABLE 8. Breakdown of Corporate Foundation 9/11 Response Funding by Foundation Asset Size*

\begin{tabular}{lcrrr}
\hline & $\begin{array}{c}\text { No. of } \\
\text { Foundations }\end{array}$ & \multicolumn{1}{c}{$\%$} & \multicolumn{1}{c}{$\begin{array}{c}\text { 9/11 Giving } \\
\text { Amount }\end{array}$} & \multicolumn{1}{c}{$\%$} \\
\hline \$250 million and over & 8 & 3.6 & $\$ 26,756,096$ & 7.7 \\
$\mathbf{\$ 5 0}$ million-\$250 million & 31 & 14.0 & $106,100,756$ & 30.4 \\
$\mathbf{\$ 1 0}$ million-\$50 million & 62 & 27.9 & $98,802,333$ & 28.3 \\
\$1 million-\$10 million & 54 & 24.3 & $63,266,072$ & 18.1 \\
Under \$1 million & 41 & 18.5 & $41,623,192$ & 11.9 \\
Not available & 26 & 11.7 & $12,515,625$ & 3.6 \\
\multicolumn{1}{c}{ TOTAL } & $\mathbf{2 2 2}$ & $\mathbf{1 0 0 . 0}$ & $\mathbf{\$ 3 4 9 , 0 6 4 , 0 7 4}$ & $\mathbf{1 0 0 . 0}$ \\
\hline
\end{tabular}

Source: Giving in the Aftermath of 9/11, The Foundation Center,

November 2002

*Based on assets for latest fiscal year reported (2001 for most foundations, 2000 for others); due to rounding, percentages may not total 100 .

\section{Recipients}

The following is an analysis of donations from institutional donors to approximately 1,150 recipient groups, including relieffunds created by relief agencies, government agencies, corporations, and foundations to aid 9/11 victims and affected communities; emergency relief and other service providers; local nonprofits directly affected by the disaster and its aftermath; and organizations working on issues related to the attacks. As part of our tracking effort, the Foundation Center has created a recipient database and classified recipients by organization type. During 2003, in the second phase of this project, we will track the ultimate distribution and use of contributions by major relief funds and other recipients. (For a first look at 9/11 relief fund distributions, see page 17.)

- Three-fifths of the more than $\$ 1.0$ billion pledged by foundations, corporations, and other institutional donors supported 173 relief funds created after $9 / 11$ to aid victims, their families, and other persons and communities affected by the disaster, mainly through regranting (Figure 8). These intermediaries included general- and specialpurpose funds created by relief agencies and other nonprofits and also funds created by institutional donors, especially corporations, community and other public foundations, federated funds, and associations. ${ }^{13}$

- The September 11th Fund is the largest 9/11 relief fund ranked by amount received from institutional donors (\$144.2 million, or 14 percent) and number of gifts (409). It also ranks as the top recipient in the Foundation Center's database overall (Table 9). The Fund's broad purpose includes providing direct assistance to victims and their families and services to affected communities. Excluding donations raised for the Fund in a national telethon, foundations and corporations provided nearly 38 percent of the Fund's reported \$378 million in private support. (Including the telethon pledges, the Fund received $\$ 506$ million. $)^{14}$

- The American Red Cross Liberty Disaster Relief Fund, which raised funds for victims and their families and also provided direct services, ranked second in institutional donor contributions (\$133.3 million, or 13 percent) and in number of gifts (300). Yet, compared with the September 11th Fund, foundations and corporations provided a much smaller, 13 percent share of the Liberty Fund's $\$ 1$ billion of overall support, most 
of which came from individuals. ${ }^{15}$ The Liberty Fund captured roughly 38 percent of all private $9 / 11$ response funding, which is estimated at $\$ 2.6$ billion.

- Other top 9/11 relief fund recipients of institutional donors' gifts included the Twin Towers Fund (\$32.4 million) and the New York Police and Fire 9/11 Widows' and Children's Benefit
Fund (\$25.3 million). Both funds were established to aid the families of New York City police, firefighters, and rescue workers who were victims of the attacks.

- Relief funds created by more than 50 corporations to aid victims (especially employees) and their families and to support relief and recovery efforts together received $\$ 166.0$ million, or 16

FIGURE 8. Foundation/Corporate 9/11 Response Funding by Type of Recipient*

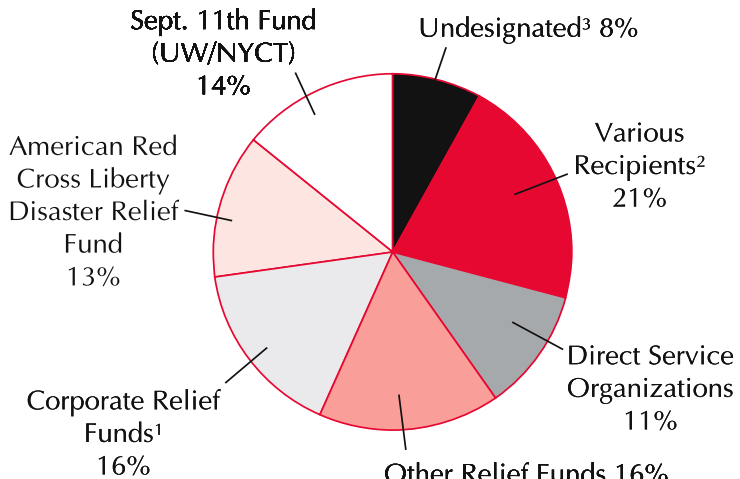

Total 9/11 Giving $=\$ 1,011.4$ million

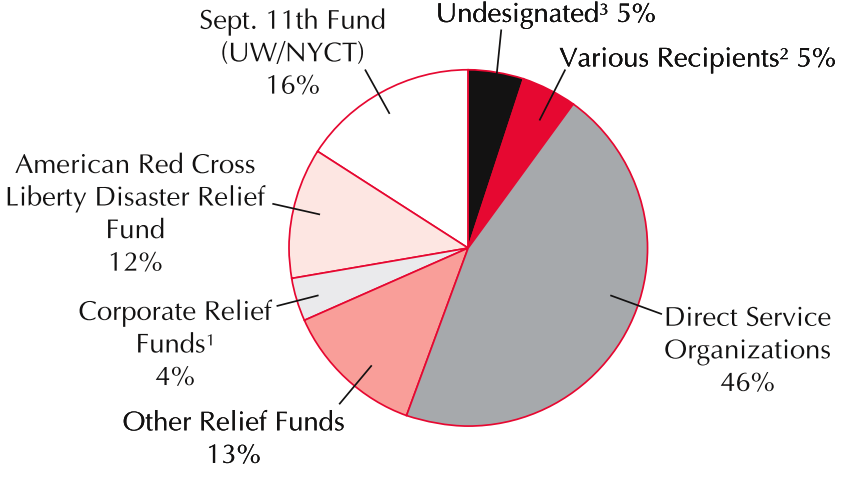

No. of $9 / 11$ Gifts $=2,566$

Source: Giving in the Aftermath of 9/11, The Foundation Center, November 2002.

*Due to rounding, percentages may not total 100 .

${ }^{1}$ Regranting funds established by individual companies after 9/11.

${ }^{2}$ Various recipients named, but amount not reported by recipient; includes grants to unspecified individuals totaling $\$ 2,965,000$.

${ }^{3}$ No recipient named at time of pledge.

TABLE 9. Top 20 Designated Recipients of Foundation/Corporate 9/11 Response Funding*

\begin{tabular}{|c|c|c|c|c|}
\hline Recipient/Recipient Fund & State & Amount $^{1}$ & $\begin{array}{l}\% \text { of Total } \\
\text { Funding }\end{array}$ & $\begin{array}{l}\text { No. of } \\
\text { Gifts }\end{array}$ \\
\hline 1. September 11th Fund of the United Way of NY and New York Community Trust & NY & $\$ 144,200,868$ & 14.3 & 409 \\
\hline 2. American Red Cross Liberty Disaster Relief Fund ${ }^{2}$ & DC & $133,251,868$ & 13.2 & 300 \\
\hline 3. New York City Public/Private Initiatives_-Twin Towers Fund & NY & $32,419,861$ & 3.2 & 46 \\
\hline 4. NY Police \& Fire 9/11 Widows' and Children's Benefit Fund & NY & $25,268,200$ & 2.5 & 16 \\
\hline 5. Salvation Army & VA & $17,403,880$ & 1.7 & 18 \\
\hline 6. Citizens' Scholarship Foundation_Families of Freedom Scholarship Fund & $\mathrm{MN}$ & $11,727,500$ & 1.2 & 13 \\
\hline 7. MLB-MLBPA Disaster Relief Fund & NY & $10,250,000$ & 1.0 & 3 \\
\hline 8. Community Foundation for the National Capital Region-Survivors' Fund and other purposes & DC & $8,372,500$ & 0.8 & 13 \\
\hline 9. Robin Hood Foundation—Robin Hood Relief Fund & NY & $8,120,000$ & 0.8 & 5 \\
\hline 10. New York State World Trade Center Relief Fund & NY & $6,116,247$ & 0.6 & 10 \\
\hline 11. Greater Kansas City Community Foundation-September 11th Fund and other purposes & $\mathrm{MO}$ & $6,085,573$ & 0.6 & 4 \\
\hline 12. New York University-NYU WLRK Scholarship Fund and other purposes & NY & $5,350,000$ & 0.5 & 3 \\
\hline 13. New York Foundation for the Arts & NY & $3,525,000$ & 0.3 & 7 \\
\hline 14. Fund for Public Schools-World Trade Center School Relief Fund & NY & $3,350,000$ & 0.3 & 2 \\
\hline 15. New York City Police Foundation Heroes Fund & NY & $3,250,000$ & 0.3 & 5 \\
\hline 16. International Association of Fire Fighters-New York Firefighters 9-11 Disaster Relief Fund & NY & $2,946,541$ & 0.3 & 27 \\
\hline 17. American Music Center-Music Liberty Initiative for New York & NY & $2,750,000$ & 0.3 & 2 \\
\hline 18. Alliance of Resident Theaters/New York-September 11th Fund & NY & $2,750,000$ & 0.3 & 2 \\
\hline 19. SEEDCO_Lower Manhattan Small Business \& Workforce Retention Program & NY & $2,650,000$ & 0.3 & 3 \\
\hline 20. Heroes of New York Scholarship Fund & NY & $2,500,000$ & 0.2 & 1 \\
\hline
\end{tabular}

Source: Giving in the Aftermath of 9/11, The Foundation Center, November 2002.

*Excludes relief funds established by individual corporate donors.

${ }^{1}$ Excludes undesignated pledges and unspecified amounts donated to named recipients.

${ }^{2}$ Includes all contributions to headquarters for 9/11-related efforts. 
percent of institutional funding. Eight corporate funds received at least $\$ 10$ million in support (Table 10). The largest relief fund recipient by far was the Citigroup Relief Fund, which received $\$ 15$ million from Citigroup Foundation to provide scholarships for the children of victims.

- 978 direct service providers, groups directly affected by the $9 / 11$ attacks, and organizations addressing issues related to the attacks and their aftermath received $\$ 109.8$ million, or 11 percent of funding. These organizations received 1,178 donations from institutional funders, or 46 percent of their gifts.

- The Salvation Army was the top direct service recipient, with contributions from foundations and corporations totaling $\$ 17.4$ million. In all, eleven organizations and institutions received $\$ 1$ million or more from donors-mainly foundations-for such direct services as outreach, emergency needs, special programming, and advocacy. Close to 250 groups received $\$ 100,000$ or more. The large majority of service providers received less than $\$ 50,000$.

- Twenty-nine percent of institutional giving (\$290.0 million) could not be assigned to a recipient because donors either did not break down amounts pledged to named recipients ( $\$ 215.8$ million, or 21 percent) or did not designate a recipient ( $\$ 77.2$ million, or 8 percent). ${ }^{16}$

\section{By Donor Type}

- Corporate donors pledged 23 percent of their 9/11 funding (\$156.7 million) to corporate relief funds, 17 percent to the American Red Cross Liberty Disaster Relief Fund, 13 percent to the September 11th Fund, and more than 15 percent to other relief funds, especially the Twin Towers Fund and the New York Police and Fire 9/11 Widows' and Children's Benefit Fund (Figure 9). Just 2 percent of corporate giving (\$14.9 million) supported direct service agencies. One-fifth of corporate pledges ( $\$ 140.6$ million) could not be allocated by recipient, while 9 percent ( $\$ 58.6$ million) was undesignated. (A portion of corporate donors' undesignated giving represents funds pledged to match employee gifts.)

- Independent and community or other public foundations gave 17 percent of their 9/11 funding (\$52.2 million) to the September 11th Fund but less than 6 percent to the American Red Cross Liberty Disaster Relief Fund; another 20 percent of donations went to various other relief funds (Figure 10). In contrast with corporate donors, the largest single share of foundation funding — \$90.6 million, or 29 percent-supported direct service organizations active in relief and recovery efforts or addressing issues related to the attacks. Similar to corporate giving patterns, 23 percent of funds ( $\$ 70.3$ million) could not be broken down by recipient, and under 6 percent (\$17 million) of pledges was undesignated. ${ }^{17}$

TABLE 10. Top 15 Corporate Relief Fund Recipients of Corporate 9/11 Response Funding*

\begin{tabular}{|c|c|c|c|c|}
\hline Corporate Relief Fund & State & Amount $^{1}$ & $\begin{array}{l}\% \text { of Total Corporate } \\
\text { Funding }\end{array}$ & $\begin{array}{l}\text { No. of } \\
\text { Gifts }\end{array}$ \\
\hline 1. Citigroup Relief Fund & NY & $\$ 15,000,000$ & 2.2 & 1 \\
\hline 2. J. P. Morgan Chase WTC Disaster Relief Fund & NY & $11,972,956$ & 1.8 & 2 \\
\hline 3. Marsh \& McLennan Victims' Relief Fund & NY & $10,150,000$ & 1.5 & 3 \\
\hline 4. Goldman Sachs Relief Fund & NY & $10,010,000$ & 1.5 & 1 \\
\hline 5. AXA 9/11 Relief Fund & NY & $10,000,000$ & 1.5 & 1 \\
\hline 6. Bear Stearns Relief Fund & NY & $10,000,000$ & 1.5 & 1 \\
\hline 7. DaimlerChrysler Help the Children Fund & $\mathrm{MI}$ & $10,000,000$ & 1.5 & 1 \\
\hline 8. Morgan Stanley Victims Relief Fund & NY & $10,000,000$ & 1.5 & 1 \\
\hline 9. New York Times $9 / 11$ Neediest Fund ${ }^{2}$ & NY & $7,250,100$ & 1.1 & 9 \\
\hline 10. Homebuilders Care Victims' Relief Fund ${ }^{3}$ & DC & $7,000,000$ & 1.3 & 7 \\
\hline 11. Prudential CARES Disaster Relief Fund & NJ & $6,163,407$ & 0.9 & 2 \\
\hline 12. Cantor Fitzgerald Relief Fund & NY & $6,069,666$ & 0.9 & 5 \\
\hline 13. DisneyHand: Survivor Relief Fund & $\mathrm{CA}$ & $5,000,000$ & 0.7 & 1 \\
\hline 14. BP Employee Disaster Relief Fund & $\mathrm{IL}$ & $4,266,667$ & 0.6 & 1 \\
\hline 15. AMEX WTC Disaster Relief Fund & NY & $4,100,000$ & 0.6 & 1 \\
\hline
\end{tabular}

Source: Giving in the Aftermath of 9/11, The Foundation Center, November 2002.

* Regranting funds established by individual companies after $9 / 11$ to assist victims and their families.

${ }^{1}$ Amount includes pledges and matching gifts from the institutional donors in the 9/11 response database only; excludes funds contributed by employees.

${ }^{2}$ Fund received additional $\$ 2.1$ million in gifts from independent and public foundations.

${ }^{3}$ Includes gifts from 7 corporate donors made through the National Housing Endowment. 
- Corporations and foundations differed strikingly in the degree to which they supported relief funds. Corporations gave 73 percent of their 989 gifts to corporate and other relief funds and only 13 percent to direct service organizations. Another 16 percent is as yet undesignated or unspecified. In contrast, 68 percent of foundations' 1,561 gifts went to direct service organizations, including nonprofits affected by 9/11 and those working on related issues, while only 27 percent went to relief funds. A modest 6 percent of foundation gifts is either undesignated or cannot be allocated by recipient.

FIGURE 9. Corporate 9/11 Response Funding by Type of Recipient*

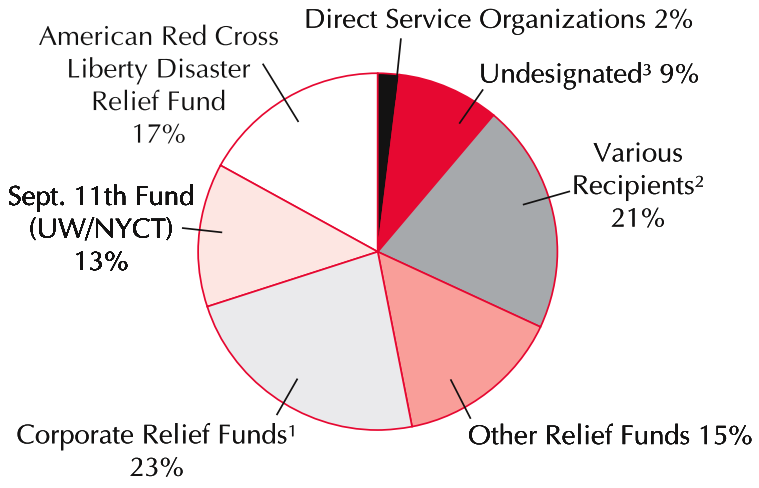

Total 9/11 Giving $=\$ 682.4$ million

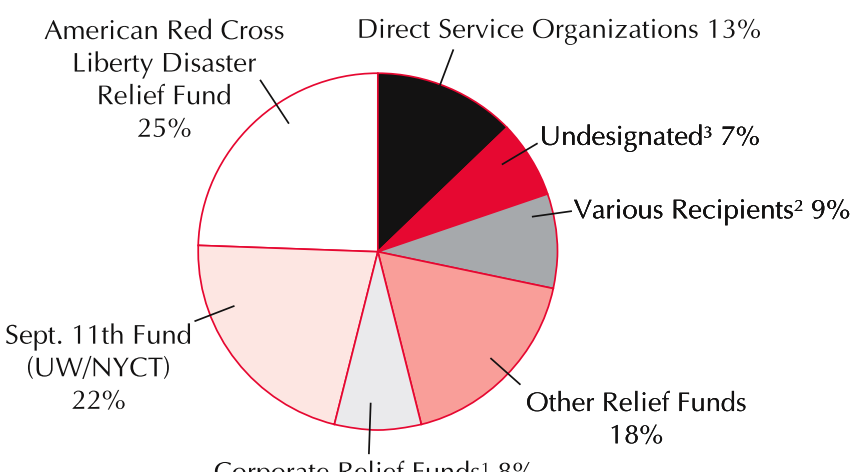

Corporate Relief Funds $18 \%$

No. of $9 / 11$ Gifts $=989$

Source: Giving in the Aftermath of 9/11, The Foundation Center, November 2002.

*Donors include 568 corporations and corporate foundations; due to rounding, percentages may not total 100.

${ }^{1}$ Regranting funds established by individual companies.

${ }^{2}$ Various recipients named, but amount not reported by recipient.

${ }^{3}$ No recipient named at time of pledge.

FIGURE 10. Foundation 9/11 Response Funding by Type of Recipient*

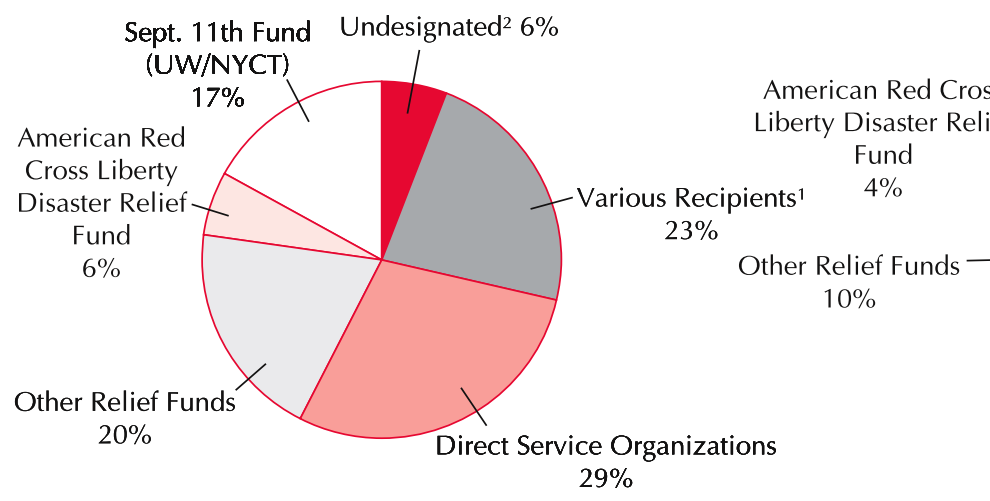

Total 9/11 Giving $=\$ 309.2$ million
Sept. 11th Fund

(UW/NYCT) Undesignated ${ }^{2} 4 \%$

\begin{tabular}{l|l}
$13 \%$ & Various Recipients \\
& $13 \%$
\end{tabular} 


\section{By Recipient Location}

- Foundations and corporations supported 9/11 relief funds and service organizations located in 42 states and eleven countries, including Afghanistan and Pakistan. New York area funds and recipients garnered $\$ 414.5$ million, or more than two-fifths of all 9/11 response funding (Figure 11). They received 1,196 gifts, or 47 percent of the total, including many of those to direct service providers and groups affected by the attacks.

- Including gifts to the American Red Cross Liberty Disaster Relief Fund, the District of Columbia ranked second by dollars received (\$164.9 million) and number of grants (426). Virginia, where the Salvation Army is headquartered, ranked third by dollars received. Organizations in nine states received more than $\$ 10$ million from foundations and corporations for 9/11-related causes. Recipients included local 9/11 relief funds, local chapters of the American Red Cross and Salvation Army, fire departments and emergency services, and nonprofits working locally, nationally, and internationally on issues related to the attacks.

FIGURE 11. Foundation/Corporate 9/11 Response Funding by Recipient Location*

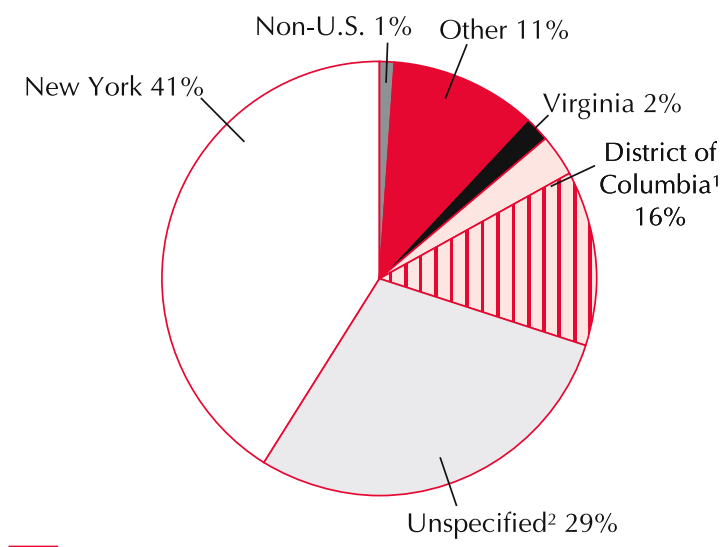

ПAmerican Red Cross

Total 9/11 Giving $=\$ 1,011.4$ million

Source: Giving in the Aftermath of 9/11, The Foundation Center,

November 2002.

*Due to rounding, percentages may not total 100.

'In the 9/11 response database, all gifts to the American Red Cross (ARC)

Liberty Disaster Relief Fund are accounted for in the District of Columbia,

which houses ARC headquarters.

Includes grants to various organizations for unspecified amounts and undesignated pledges.

\section{By Recipient Field of Activity}

As noted above, recipients fell into two broad categories: 9/11 relief funds and direct service agencies. The following is an analysis of funding for direct service organization recipients by principal field of activity. Recipients were coded using the National Taxonomy of Exempt Entities (NTEE). Direct service organizations received more than 1,170 gifts totaling nearly \$110 million, mainly from foundations. Of that total, roughly $\$ 105$ million could be identified by recipient field.

- Human service providers received nearly 39 percent of all 9/11 funding for direct service organizations ( $\$ 40.9$ million) and 42 percent of the gifts (466) (Figure 12 and Table 11). Funding supported multipurpose human service agencies, especially the Salvation Army and 37 chapters of the American Red Cross, but also agencies working in such areas as food distribution, housing and shelter, crime and abuse prevention, legal services, youth services, employment, and safety/emergency services. Included among the largest multipurpose recipients were community organizations serving Arab and other ethnic communities in New York, Michigan, and other states.

FIGURE 12. Foundation/Corporate 9/11 Direct Giving to Service Organizations by Major Recipient Field*

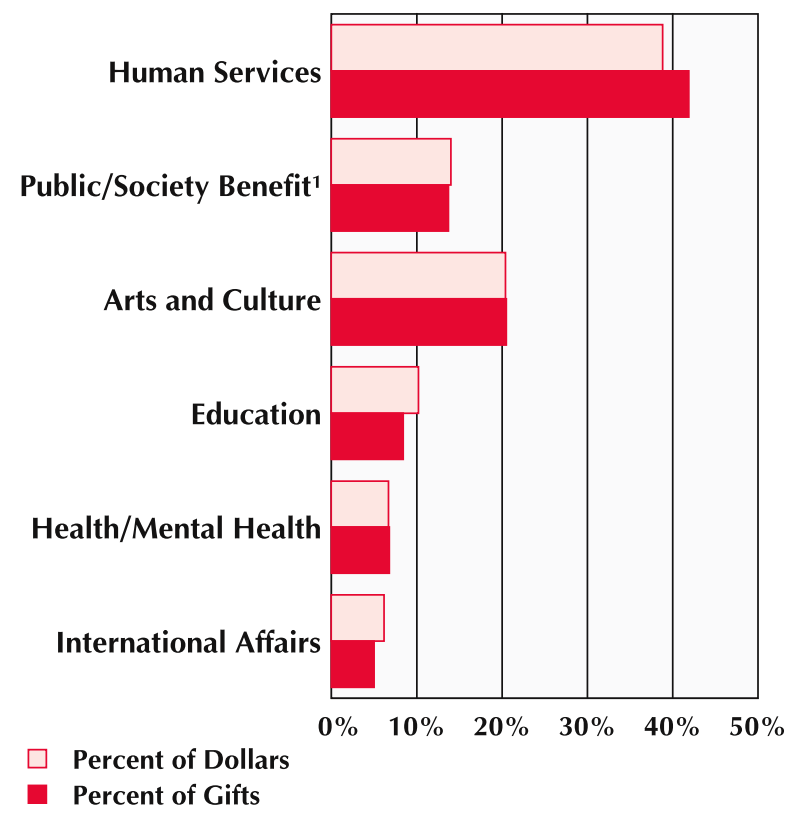

Source: Giving in the Aftermath of 9/11, The Foundation Center, November 2002.

*Includes recipient type fields representing at least 5 percent of the dollars donated directly to service organizations; excludes gifts to relief funds and other funding intermediaries.

Includes civil rights and social action, community improvement, philanthropy and voluntarism, and public affairs. 
TABLE 11. Foundation/Corporate 9/11 Direct Giving to Service Organizations by Recipient Field and Sub-Field*

\begin{tabular}{|c|c|c|c|c|}
\hline Recipient Field & Amount & $\%$ & No. of Gifts & $\%$ \\
\hline Arts and Culture & $\$ 21,494,022$ & 20.4 & 228 & 20.5 \\
\hline Education & $10,742,621$ & 10.2 & 93 & 8.4 \\
\hline Environment and Animals & $1,156,170$ & 1.1 & 20 & 1.8 \\
\hline Health & $7,084,000$ & 6.7 & 76 & 6.8 \\
\hline General Health Care & $5,491,500$ & 5.2 & 52 & 4.7 \\
\hline Mental Health & $1,592,500$ & 1.5 & 24 & 2.2 \\
\hline Human Services & $40,915,716$ & 38.8 & 466 & 41.9 \\
\hline Crime, Justice, Legal services & $2,155,311$ & 2.0 & 29 & 2.6 \\
\hline Employment & 915,792 & 0.9 & 20 & 1.8 \\
\hline Food Distribution & $2,520,500$ & 2.4 & 48 & 4.3 \\
\hline Youth Development & $1,285,812$ & 1.2 & 25 & 2.2 \\
\hline Human Services-Multipurpose & $33,161,396$ & 31.4 & 304 & 27.3 \\
\hline All Other & 876,905 & 0.8 & 40 & 3.6 \\
\hline International Affairs & $6,540,440$ & 6.2 & 56 & 5.0 \\
\hline Public/Society Benefit & $14,775,073$ & 14.0 & 153 & 13.7 \\
\hline Civil Rights & $5,135,878$ & 4.9 & 50 & 4.5 \\
\hline Community Improvement & $2,772,096$ & 2.6 & 50 & 4.5 \\
\hline Philanthropy/Voluntarism & $4,915,824$ & 4.7 & 33 & 3.0 \\
\hline Public Affairs & $1,951,275$ & 1.8 & 20 & 1.8 \\
\hline Science and Social Science & $1,800,970$ & 1.7 & 7 & 0.6 \\
\hline Religion & 972,000 & 0.9 & 14 & 1.3 \\
\hline TOTAL & $\$ 105,481,012$ & 100.0 & 1,113 & 100.0 \\
\hline
\end{tabular}

Source: Giving in the Aftermath of 9/11, The Foundation Center, November 2002.

* Includes giving to agencies and organizations that provide services or conduct programs; excludes gifts to 9/11 relief funds, scholarship funds, and other funding intermediaries.

- Arts and culture groups account for the second largest share of $9 / 11$ funding dollars (\$21.5 million, or more than 20 percent) and of gifts (228, or more than 20 percent) to service organizations. ${ }^{18}$ The vast majority of gifts supported performing and visual arts groups and museums in the New York metropolitan area that suffered displacement or loss of income following the attacks. (Several New York foundations responded to the emergency needs of small and mid-size groups and individual artists, either directly or through grants to arts funds and technical assistance providers, such as the New York Foundation for the Arts.) Cultural recipients included public broadcasting and other media organizations in New York, as well as in a number of other cities.

- Public/society benefit organizations ranked third by share of 9/11 funding for service organizations (\$14.8 million, or 14 percent) and share of gifts (153, or nearly 14 percent). More than a third of funds supported civil rights and other advocacy groups, such as the New York Immigrant Coalition, Arab-American Anti-Discrimination Committee (DC), and Capital Unity Council (CA). Gifts also supported philanthropy organizations, such as community foundations and United Ways, national public affairs groups, and community improvement organizations active in recovery and rebuilding efforts. In the last category, the top recipient was the Regional Plan Association of New York, which has convened the Civic Alliance to Rebuild Downtown New York (in partnership with New School University, New York University, and Pratt Institute) to develop strategies for redeveloping lower Manhattan.

- Educational organizations and institutions received roughly 10 percent of $9 / 11$ funding (\$10.7 million) and 8 percent of grants (93) for service organizations. In New York City, funds were targeted to elementary and secondary schools and higher education institutions directly affected by the attacks. Gifts were also made to colleges and universities across the country and around the world for activities addressing issues related to the attacks.

- The majority of the remaining $9 / 11$ funds for service organizations supported hospitals, blood banks, and emergency medical services serving affected communities; counseling and mental health groups around the country; and international affairs, relief, and human rights groups in the United States and overseas. Small amounts of funding also went to social science research groups, environment and animal welfare organizations, and churches and interfaith councils. 


\section{Impact of 9/11 Response Funding on Prospects for Giving}

The more than $\$ 1.0$ billion in 9/11 response funding provided by foundations, corporations, and other institutional donors in such a short time frame is unprecedented. Still, the scale of this funding should be kept in perspective. The $\$ 280$ million donated by independent and community foundations represented less than 1 percent of the estimated $\$ 26$ billion they gave to all causes in 2001. In contrast, the $\$ 682$ million pledged by corporations represented more than 7 percent of the estimated $\$ 9.1$ billion they contributed in the same year. ${ }^{19}$ These findings suggest that the overwhelming philanthropic response to $9 / 11$ may have weakened corporate funding capacity in 2002, whereas the impact on foundation giving levels was probably modest.

Of far greater consequence in terms of impact on funding capacity, especially of endowed foundations, has been the faltering economy and declining stock market. In a survey of 9/11 donors conducted earlier this year, grantmakers emphasized that it was the continuing stock market slide-starting well in advance of September 2001-and not 9/11 giving that was clouding their future giving prospects and driving changes in grantmaking practice. ${ }^{20}$ Yet, despite market losses, most grantmakers expected their giving to remain stable through 2002. The outlook for 2003 and beyond was gloomy. Nearly all surveyed funders were worried about the health of nonprofits in their communities and about their ability to fund programs adequately in the future.

\section{Endnotes}

1. See Renz, L., Giving in the Aftermath of 9/11: Foundations and Corporations Respond, New York, NY: Foundation Center, February 2002. Findings were based on data compiled through December 2001.

2. In 2002,576 donors provided information on their $9 / 11$ giving through Foundation Center surveys. Funders were asked to verify or update their $9 / 11$ giving information and to indicate the amount and purpose of gifts to each recipient.

3. Since the publication of the first edition of Giving in the Aftermath of 9/11 in February 2002, the number of $9 / 11$ donors identified by the Foundation Center has increased by roughly 30 percent, while the total for $9 / 11$ giving has risen by almost 12 percent. These increases reflect both more complete reporting by donors of their $9 / 11$ giving and contributions made after the Giving in the Aftermath of 9/11 report was completed.

4. The estimate of total private $9 / 11$ response funding includes an estimated $\$ 2.3$ billion raised by major relief funds from all sources (see Greene, $S$. "In Disaster's Wake," Chronicle of Philanthropy, September 5, 2002), and an estimated $\$ 250+$ million tracked by the Foundation Center in gifts from institutional donors to corporate relief funds (mainly for individual beneficiaries) and direct service providers. Still, because of incomplete information and inter-fund transfers, foundation and corporate $9 / 11$ gifts cannot be fully allocated to these recipients. As a result, the figure for all 9/11 giving is subject to change.

5. See Brown, M., Giving USA 2002: The Annual Report on Philanthropy for the Year 2001, Indianapolis, IN: AAFRC Trust for Philanthropy, 2002

6. Since publication of the first edition of Giving in the Aftermath of 9/11 in February 2002, the number of gifts tracked has more than doubled (from $1,183)$. This increase reflects more detailed and complete reporting by donors of recipient names and gift amounts. Many foundations that announced large pledges immediately following the attacks waited to assess needs before earmarking the funds for specific recipients.

7. For the purpose of this analysis, giving by separate corporate-directed entities-including corporate foundations, corporate direct giving programs, and corporate affiliates and subsidiaries-has been collapsed into a single $9 / 11$ giving figure tied to the corporate parent.

8. Some companies reporting matching gifts did not provide an exact dollar figure. As a result, the actual figure for 9/11-related employee matching gifts is likely higher.

9. An international endowed philanthropy with a principal domicile outside the United States, the Atlantic Philanthropies operates like an independent foundation and maintains a grant selection and administration office in New York.

10. Since corporate direct giving programs do not maintain assets, comparisons can only be made with corporate foundations.

11. By comparison, only 8 percent of United States foundations overall held assets of $\$ 10$ million or more, while only 2 percent held assets of $\$ 50$ million or more. Fiscal year reported was 2001 for most foundations, 2000 for others.

12. By comparison, 14 percent of the nation's roughly 2,000 corporate foundations held assets of $\$ 10$ million or more, while less than 4 percent held assets of $\$ 50$ million or more. More than half held less than $\$ 1$ million in assets.

13. Due to more complete reporting by donors, the total number of relief funds tracked in the Foundation Center's $9 / 11$ database has increased by more than 70 since publication of the first edition of Giving in the Aftermath of 9/11 in February 2002.

14. See September 11th Fund of the United Way of New York and the New York Community Trust, "Contributions," available from www.uwnyc.org/sep11/contributions.html; Internet; accessed 10/9/02.

15. See American Red Cross, "September 11, 2001: Unprecedented Events, Unprecedented Response," available from www.redcross.org; Internet; accessed on $10 / 10 / 02$.

16. Since publication of the first edition of Giving in the Aftermath of 9/11 in February 2002, the proportion of undesignated pledges has decreased, while the proportion of giving that is not broken down by recipient has increased. More complete reporting will likely lead to an increase in the contribution totals of top recipients. The Foundation Center will continue to seek detailed gift information from donors in an effort to reduce the number of gifts recorded as undesignated and to allocate specific gift amounts to named recipients.

17. Unspecified funds include $\$ 50$ million set aside by the Andrew W. Mellon Foundation to benefit New York City arts and culture groups affected by 9/11 events. Although several rounds of awards have been made, a complete listing of recipients and gift amounts was not available for processing before these data were compiled.

18. Funding for the arts is expected to more than triple once information on $9 / 11$ giving by the Andrew W. Mellon Foundation in the Foundation Center's database is complete (see also Endnote no. 17).

19. Since not all corporate $9 / 11$ pledges were paid in 2001, this comparison overestimates the share of overall corporate giving directed to the 9/11 response. Nonetheless, this comparison provides a useful yardstick for the scale of corporate support. For more information on overall 2001 corporate giving, see Brown, M., Giving USA 2001, Indianapolis, IN: AAFRC Trust for Philanthropy, 2002.

20. See Renz, L., Assessing the Post-9/11 Funding Environment: Grantmakers' Perspectives, New York, NY: Foundation Center, 2002. 


\section{Appendix}

\section{Tracking Distributions from 9/11 Relief Funds: A Preview}

\section{by Elizabeth Cuccaro and Loren Renz}

This analysis examines distributions by a sample of 30 of the largest 9/11 relief funds ranked by total amount raised from all sources. ${ }^{1}$ These funds account for the vast majority of dollars raised and disbursed by the more than 200 relief funds created after 9/11 to aid victims, their families, and other persons and communities affected by the disaster, mainly through regranting. While this analysis is preliminary and based on a sample of funds, it provides a useful first look at the purposes and beneficiaries of relief funds overall.

Of the 30 funds included in this analysis, twelve were formed by public charities (including relief agencies), while eleven were created by corporations or corporate foundations. Other types of sponsoring organizations included associations, a faith-based charity, a government agency, a community foundation, and a federated fund working in partnership with a community foundation.

Some of the general-purpose funds in the sample (e.g., the September 11th Fund of the United Way of New York and the New York Community Trust, the MLB-MLBPA

1. For detailed contact and purpose information on the relief funds included in the sample and on the larger set of $9 / 11$ relief funds, visit the Better Business Bureau of Metro New York's online charities database (http:// bbb.blenderbox.com/disasterrelief/charities.asp).

FIGURE A1. Purposes of 9/11 Relief Fund Distributions*

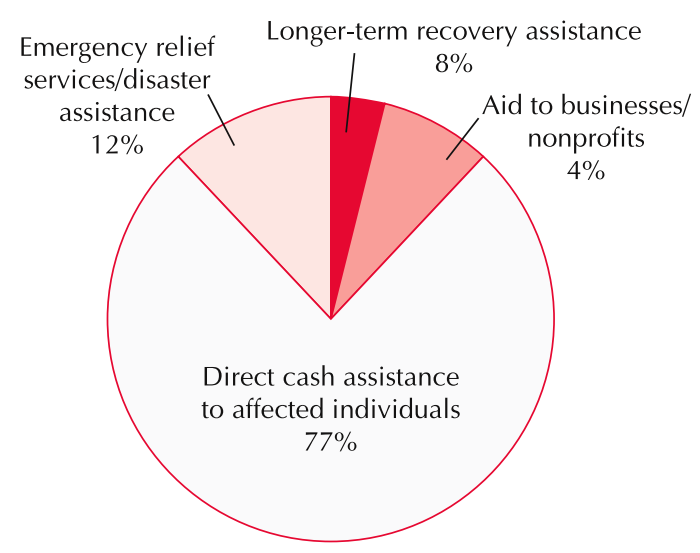

Amount Distributed $=\$ 1.7$ billion $^{1}$

Source: Giving in the Aftermath of 9/11, The Foundation Center, November 2002

*Based on a sample of 30 of the top relief funds ranked by amount raised.

${ }^{1}$ Adjusted total excludes inter-fund grants; due to rounding, percentages may not total 100.
Disaster Relief Fund, and several company-sponsored funds) re-granted a portion of the monies they raised to other funds in the sample, specifically to those funds that make direct cash payments to individuals, provide direct services, or administer long-term scholarship funds. To the extent known, amounts representing inter-fund transfers have been deducted from the aggregate distribution amount reported to avoid double counting of dollars. However, the distribution amounts reported for individual funds on the accompanying table include these inter-fund grants.

The data on 9/11 relief funds were compiled by Foundation Center staff mainly from surveys, press releases, and online sources. The Center will continue to track the distributions of 9/11 relieffunds as part of a larger effort to create the definitive record of institutional philanthropy's response to 9/11.

\section{Overview of Distributions}

- The 30 funds included in this analysis distributed close to $\$ 1.9$ billion for $9 / 11$ relief and recovery. Excluding inter-fund transfers of approximately $\$ 150$ million, these funds distributed $\$ 1.7$ billion to $9 / 11$ relief and recovery. More than half of the total (52 percent) was distributed by the two largest funds-American Red Cross Liberty Disaster

FIGURE A2. Beneficiaries of 9/11 Relief Fund Distributions*

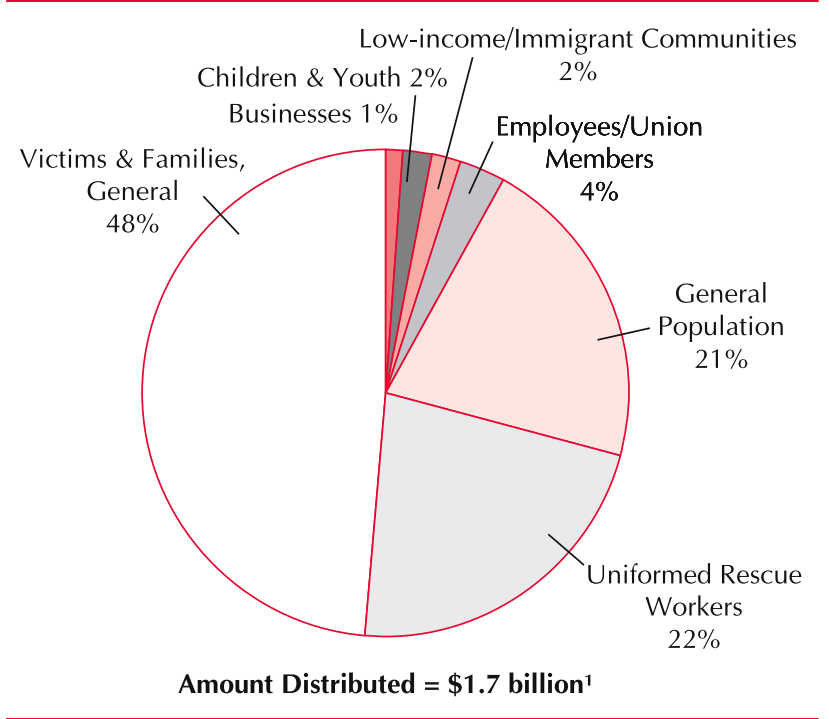

Source: Giving in the Aftermath of 9/11, The Foundation Center, November 2002

* Based on a sample of 30 of the top relief funds ranked by amount raised.

${ }^{1}$ Adjusted total excludes inter-fund grants; due to rounding, percentages may not total 100. 


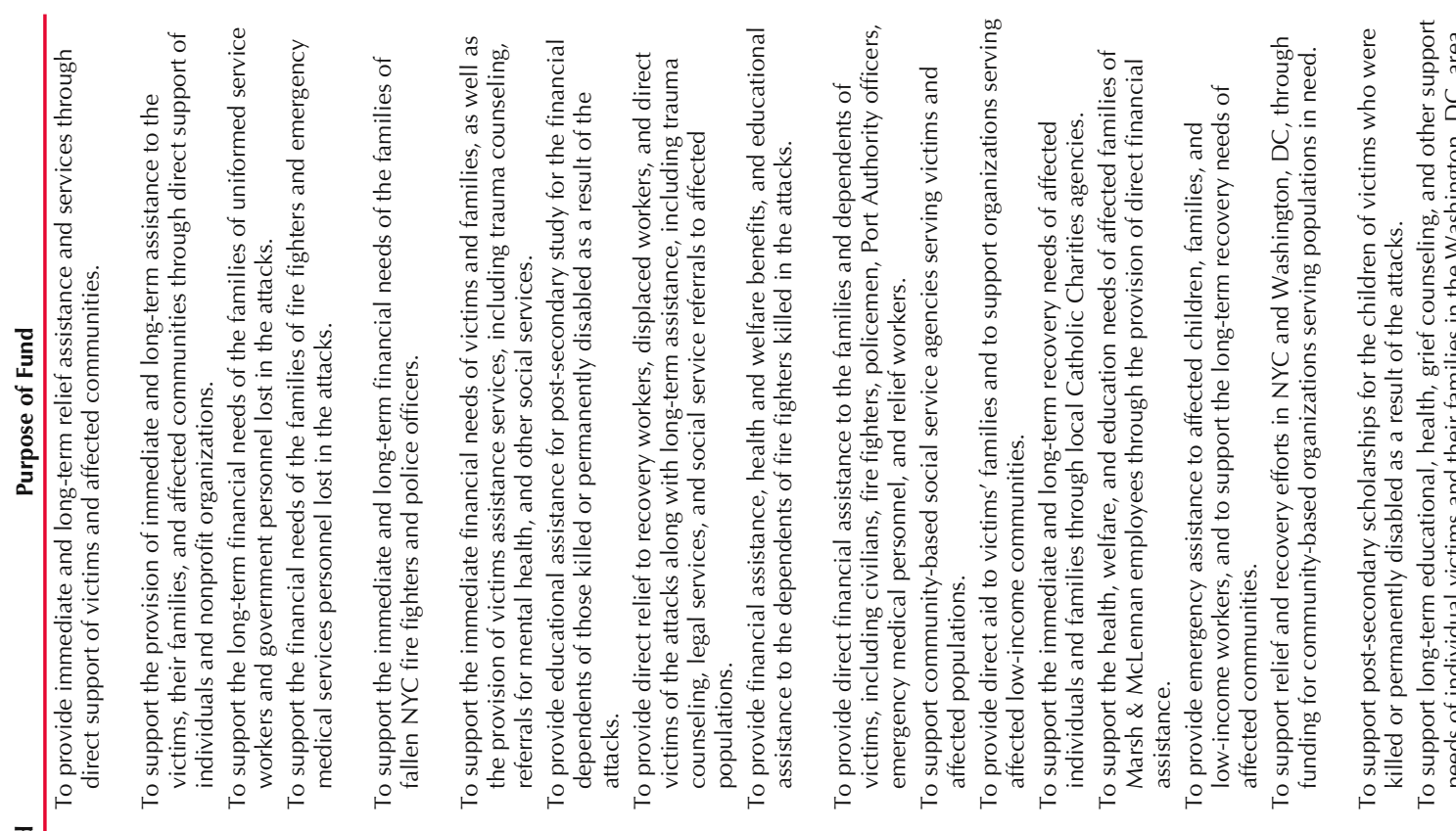

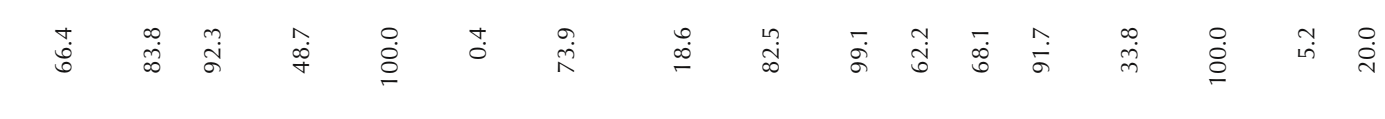

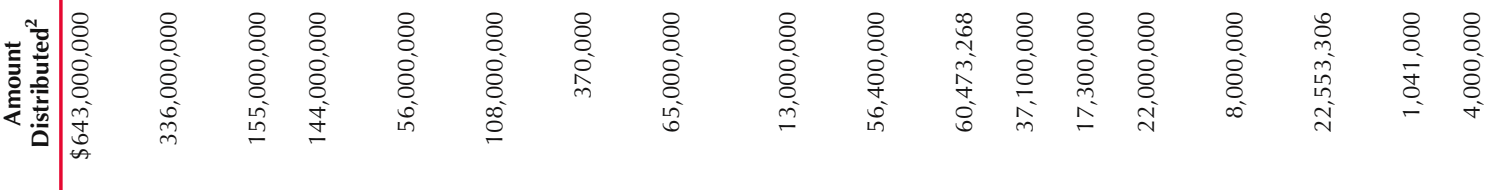

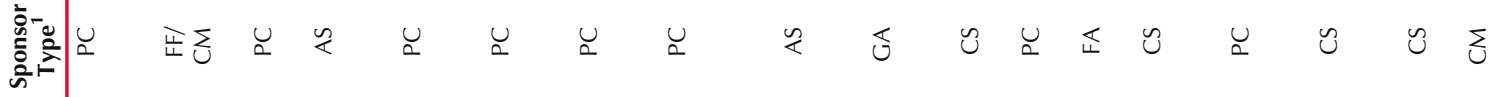

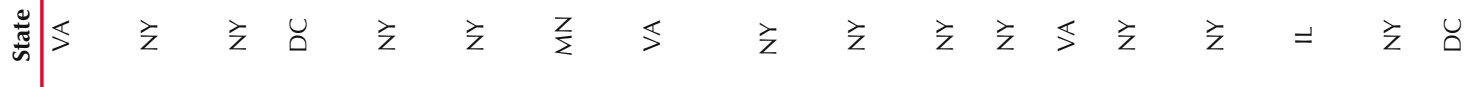

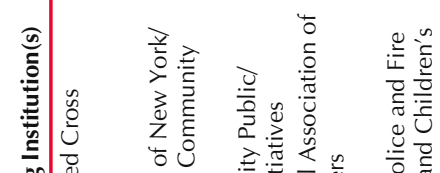

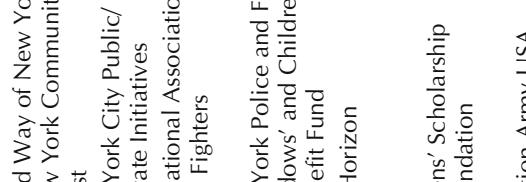

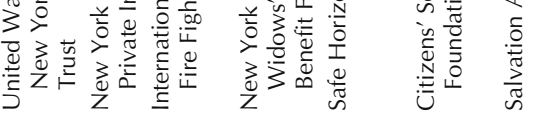

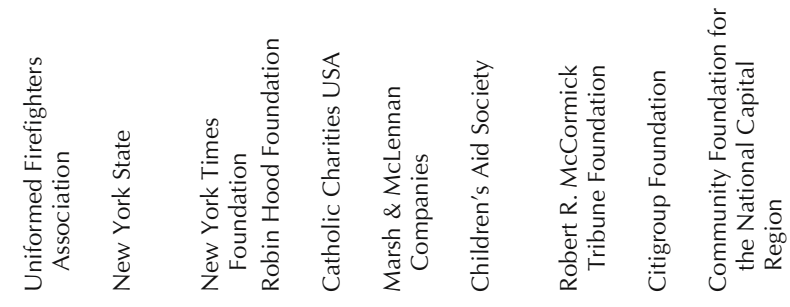

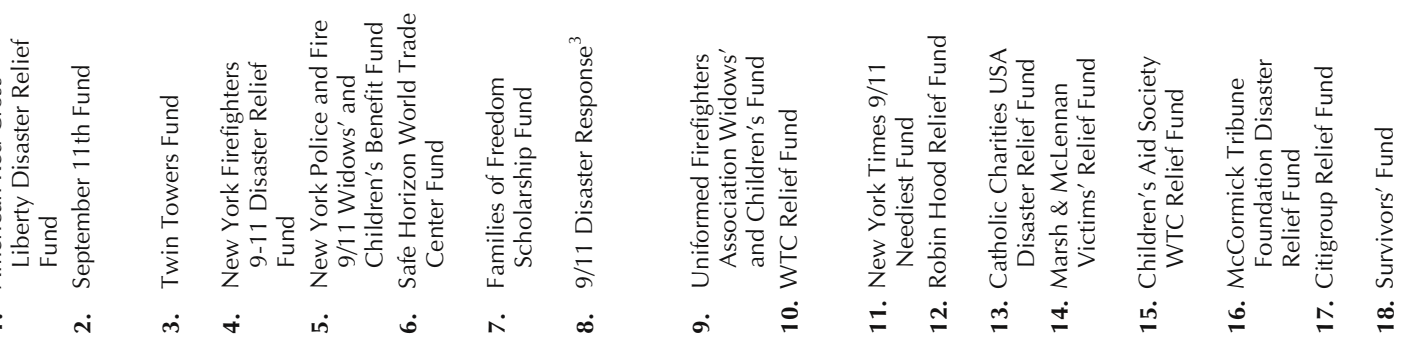




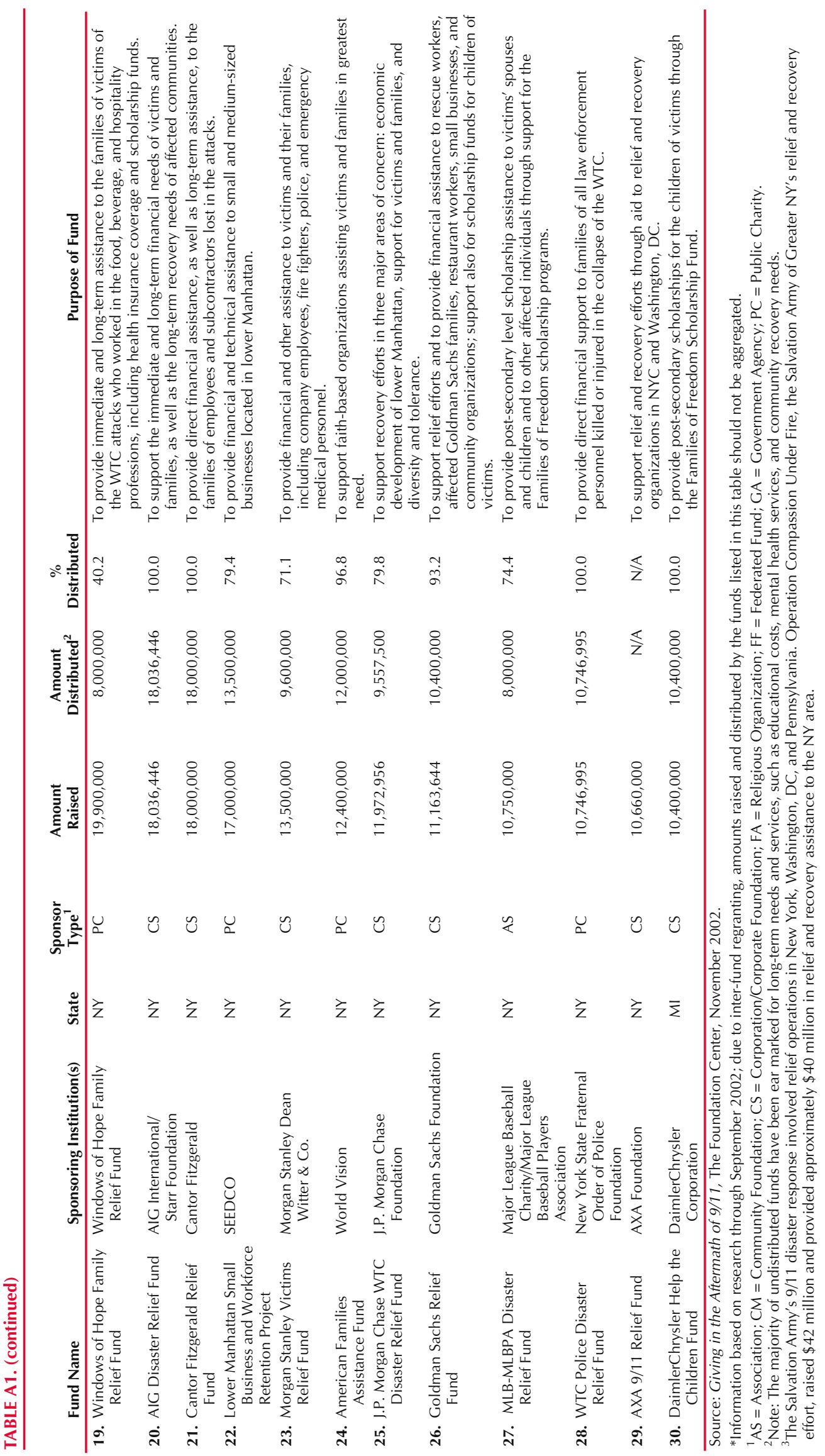


Relief Fund (\$643 million) and the September 11th Fund (\$336 million). The top five funds by amount disbursed — at least $\$ 100$ million eachaccounted for 71 percent of all distributions reported by the sampled funds.

- Eleven company-sponsored funds together distributed \$171 million, representing roughly 11 percent of all distributions reported by the sampled funds.

- Overall, excluding inter-fund regranting, 64 percent of the total amount raised by sampled funds has been distributed. ${ }^{2}$ Among companysponsored funds, 84 percent of the total amount raised has been distributed.

- More than half of sampled funds have already distributed at least three-quarters of the amount that they raised.

\section{Purposes of the Funds}

- The vast majority of distributions by sampled funds ( $\$ 1.3$ billion, or 77 percent) took the form of direct aid to victims and other affected individuals, such as those who lost their jobs.

- The second largest share of distributions (\$207 million, or 12 percent) paid for emergency rescue services and other immediate disaster assistance. The latter category included the provision of food, supplies, and temporary shelter to affected persons by sponsoring relief agencies, such as the American Red Cross and the Salvation Army.

- The third largest share of disbursements (\$129 million, or nearly 8 percent) supported longerterm recovery needs of affected individuals and communities, such as mental health counseling, financial and legal advisory services, and employment and training assistance. (This category also includes support for $9 / 11$ scholarship funds, which will provide for the long-term educational needs of children of $9 / 11$ victims.)

- The remaining funds were used for grants, loans, and technical assistance to affected businesses and nonprofits ( $\$ 60$ million, or almost 4 percent).

2. This figure excludes the one fund for which distribution information was not available; undistributed funds are mainly earmarked for long-term needs and services.
- Compared to overall patterns, company-sponsored funds in the sample allocated a smaller 63 percent of their distributions as direct aid to individuals but a much larger 30 percent to support longer-term recovery services. In addition, they allocated a moderately larger 6 percent of their support to assist affected businesses and nonprofits.

\section{Beneficiaries of the Funds}

- Victims of the attacks and their families were the principal beneficiaries of the sampled funds. Close to half of distributions (\$831 million) was targeted to the "general" victims population. ${ }^{3} \mathrm{An}$ additional 22 percent of distributions (\$383 million) was earmarked for deceased or injured firemen, policemen, and other affected uniformed rescue workers and their families.

- Other groups of victims or related beneficiaries included employees/union members (\$61 million, or close to 4 percent), low-income/immigrant communities ( $\$ 39$ million, or over 2 percent), children of victims and other children affected by the attacks (nearly $\$ 26$ million, or close to 2 percent), and businesses (\$23 million, or just over 1 percent).

- Approximately one-fifth of distributed funds (nearly \$357 million) was intended for the general population, including individuals and communities that suffered indirect effects of the attacks and nonprofit service providers supporting these populations.

3. For some relief funds, this category also includes persons directly affected by the attacks, such as those who lost their jobs.

\section{Additional Staff Contributing to this Report or the 9/11 Funding Database \\ Mark Carway, Christine Innamorato, Kevin Kinsella, Steven Lawrence, Mitch Nauffts, Rick Schoff \\ Acknowledgment}

We wish to thank the Annie E. Casey Foundation, California Endowment, ChevronTexaco, the Ford Foundation, the John S. and James L. Knight Foundation, the Lumina Foundation for Education, Morgan Stanley, and the Charles Stewart Mott Foundation for their generous support of the Foundation Center's 9/11 Philanthropic Response Project.

For more information about this report, contact Loren Renz, Vice President for Research, at 212-807-3601, or e-mail lr@fdncenter.org. This report can be accessed at no charge at the Foundation Center's Web site: www.fdncenter.org. 